\title{
THE TRANSITION ECONOMIES: A NATREX EVALUATION OF RESEARCH
}

\author{
JEROME L. STEIN \\ CESIFO WORKING PAPER NO. 1449 \\ CATEgORY 6: MONETARY POLICY and InTERnATIONAL FinanCE \\ APRIL 2005
}

An electronic version of the paper may be downloaded

- from the SSRN website:

www.SSRN.com

- from the CESifo website:

www.CESifo.de 


\title{
THE TRANSITION ECONOMIES: A NATREX EVALUATION OF RESEARCH
}

\begin{abstract}
This paper applies the NATREX model of equilibrium exchange rates to evaluate several key studies of the Central and Eastern European Countries (CEEC) in general, with particular emphasis upon the Czech Republic and Hungary and with references to Poland and Bulgaria. On the basis of the NATREX model, we evaluate several key studies to answer the questions: How can the trends in the real exchange rates of the transition economies be explained? What are sustainable trends in their real exchange rates? To what extent were the real exchange rates misaligned? What are sustainable/equilibrium current account deficits and net investment positions in the medium and in the long-run? What are the policy implications for the transition economies of the NATREX analysis?
\end{abstract}

JEL Code: F31, F32, P2.

Keywords: transition economies, NATREX model, equilibrium real exchange rates, current account deficits, euro area.

\author{
Jerome L. Stein \\ Division of Applied Mathematics \\ Brown University \\ Providence RI 02912 \\ USA \\ Jerome_Stein@Brown.edu
}

I am indebted to Kirsten Lommatzsch, Jan Frait, and Peter Karadi for criticisms of an earlier draft. This is a draft of chapter 8, Jerome L. Stein, Stochastic Optimal Control, International Finance and Debt Crises, Oxford University Press, forthcoming. 


\section{The Transition Economies: A NATREX Evaluation of}

\section{Research $^{1}$}

\section{Introduction}

The new member states of the European Union do not have an opt-out clause from the obligation to adopt the euro at some point in the future. The policy decision of the acceding countries is whether to join the European Monetary Union at an early or at a later stage after accession. At that time they must decide what irrevocable exchange rate is best suited for entry into the ERM-II. Countries participating in the Exchange Rate Mechanism peg their exchange rates to the euro, allowing for fluctuations within a symmetric band of no more than 15\% around the central parity. A prerequisite for moving from the ERM-II to adopting the euro is that there be no "major tensions" for two years in the foreign exchange markets. The main issues are: When should the country enter ERM-II? What rate should be selected? What policies should be adopted to reduce their vulnerability to crises? The criteria should be that: The selected conversion rate is sustainable. The irrevocable conversion rate should neither trigger inflation due to undervaluation, nor a loss of competitiveness caused by an over-valuation. A sustainable rate is defined as the equilibrium rate in the NATREX model $^{2}$. Economies are vulnerable to crises $^{3}$ if they have overvalued exchange rates or excess debt. This chapter applies the NATREX model of equilibrium exchange rates to evaluate several key studies of the Central and Eastern European Countries CEEC in general ${ }^{4}$ with particular emphasis upon Czech Republic and Hungary and with references to Poland and Bulgaria. In this manner we explain how one should address the main issues cited above.

Real trend currency appreciation has been observed in all of the CEEC transition economies, although the extent of real currency appreciation has varied considerably from one candidate country to another. Figure 1 graphs in normalized form the real

\footnotetext{
${ }^{1}$ I am indebted to the following for criticisms of an earlier draft. Kirsten Lommatzsch, Jan Frait, and Peter Karadi.

${ }^{2}$ The NATREX theory is developed in chapter 4, and it is applied to the euro area in chapter 7.

${ }^{3}$ The Asian crises were explained in this manner in chapter six.

${ }^{4}$ The reader is urged to read the outstanding survey article by Égert, Halpern and MacDonald, Equilibrium Exchange Rates in Transition Economies: Taking Stock of the Issues". The authors critically review the various methods for calculating equilibrium exchange rates, and provide a comprehensive evaluation of the extensive literature.
} 
effective exchange rates of Poland Hungary and the Czech Republic. The real exchange rate $\mathrm{R}=\mathrm{Np} / \mathrm{p}$ * where $\mathrm{N}$ is the nominal exchange rate (foreign currency per unit of domestic currency) and p/p* is the ratio of domestic to foreign prices. Real appreciation, which is a rise in $\mathrm{R}$, can occur either from an appreciation of the nominal rate $\mathrm{N}$, a rise in the ratio of domestic/foreign prices or a linear combination of the two.

At the beginning of transformation in 1991, all three currencies appreciated sharply in real terms due to the price effects $\left(\mathrm{p} / \mathrm{p}^{*}\right)$; and the countries increased the flexibility of their nominal exchange rate regimes over the period from 1991 to 2002. The real currency appreciation in the transition countries occurred regardless of their exchange rate regimes - floats, managed floats, pegs and currency boards. Not only did the regimes differ among countries, but also some changed their regimes over time ${ }^{5}$. Hence the division of the appreciation (rise) in $\mathrm{R}$ between the rise in $\mathrm{N}$ and the rise in $\mathrm{p} / \mathrm{p}^{*}$ varied over time. In some cases, there was nominal depreciation but real appreciation.

\footnotetext{
${ }^{5}$ Frait and Komarek (figure 3) graph the nominal and real exchange rates and inflation differentials of six transition economies. See also their figure 4. The country/time period diversity of exchange rate regimes is apparent. For example, beginning in 1991 Hungary had a relatively flexible exchange rate regime. In the major part of the 1990s Hungary had quasi-fixed/adjustable peg regimes: an adjustable peg until 1996, then a crawling peg with a band of $\pm 2.25 \%$, but low volatility. In 2001 Hungary changed to a relatively flexible band $\pm 15 \%$, a shadow ERMII regime. I argue that the NATREX - which is an equilibrium rate - contains all regimes, but the speed of convergence to the NATREX is affected by the regime - since price flexibility is limited. In each case, the real exchange rate has a trend of appreciation.
} 


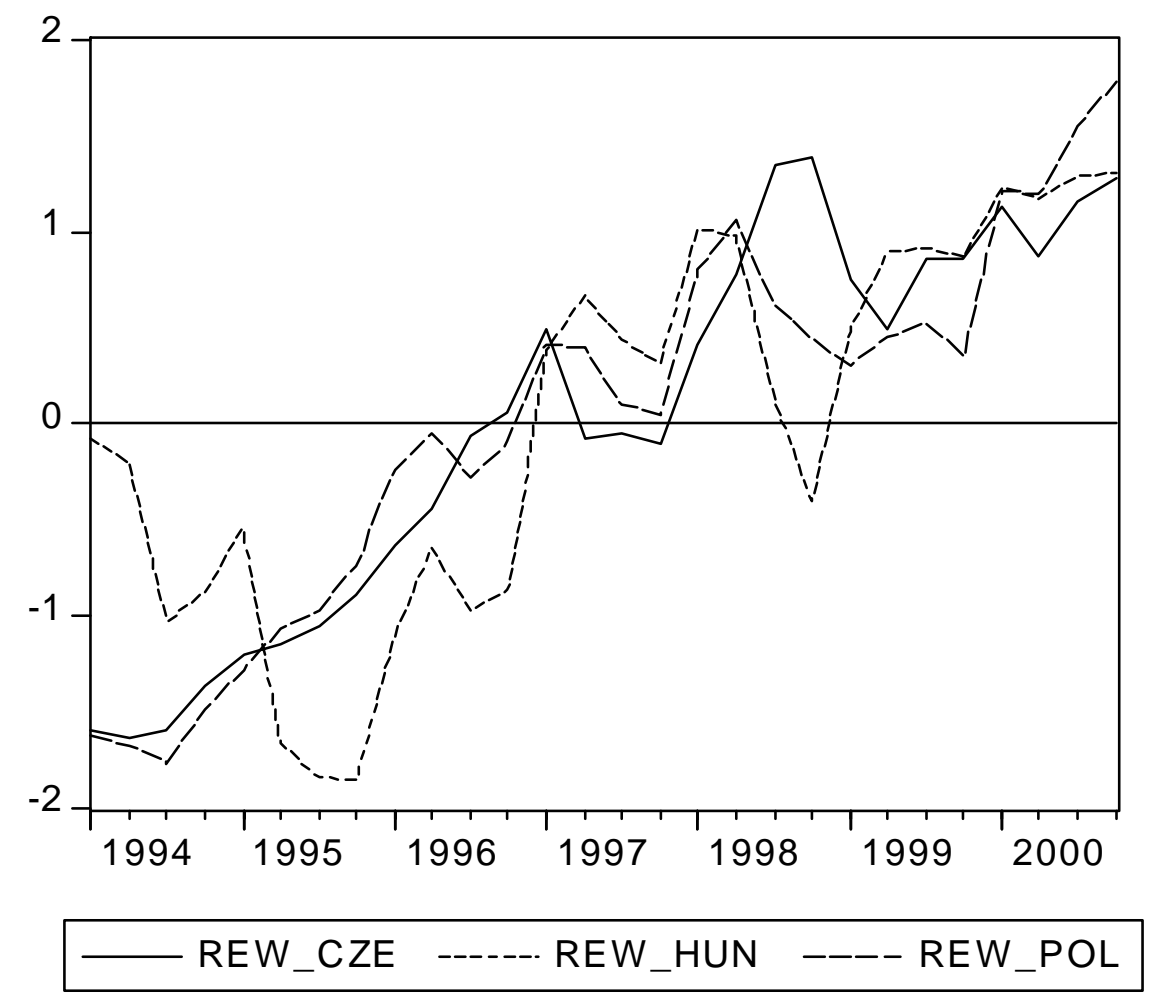

Figure 1. Real Effective exchange rates of Czech Republic (CZE), Hungary (HUN) and Poland (POL), using CPI prices, relative to OECD trading partners, normalized: (real exchange rate - mean)/standard deviation. Source: Deutsche Bundesbank.

Why did the real exchange rates of Hungary, Czech Republic and Poland significantly appreciate from 1994-95 to 2002, as seen in figure 1 ? Was the real appreciation sustainable and consistent with competitiveness? The PPP hypothesis states that: the real exchange rate reverts to a constant mean, and deviations from PPP imply misalignment. The PPP hypothesis should not be used to derive a measure of the equilibrium exchange rate in the case of these transition economies, where the structure is changing as a market economy replaces the Socialist economy. Instead we use the NATREX model to answer the questions: What are the "fundamental determinants" of the equilibrium real exchange rate, and what is the transmission mechanism between these real determinants and the equilibrium real exchange rate? Unless these questions are answered satisfactorily, a country cannot rationally decide what is a sustainable/equilbrium exchange rate for entry into the euro area, and desirable policies to follow subsequently. 
The sharp widening of current account deficits in a number of countries in 2003, and which are expected to remain high, raised questions about their sustainability and the competitiveness of these economies. For example, one effect of foreign direct investment FDI is to decrease the net investment position which will lead to subsequent outflows of dividends. Should FDI and current account deficits be causes for concern, as feared by the International Monetary Fund (WEO, April 2004)?

On the basis of the NATREX model, we evaluate several key studies to answer the questions:

- How can the trends in the real exchange rates of the transition economies be explained?

- What are sustainable trends in their real exchange rates? To what extent were the real exchange rates misaligned?

- What are sustainable/equilibrium current account deficits and net investment positions in the medium and in the long-run?

- What are the policy implications for the transition economies of the NATREX analysis?

1.1. Neither Purchasing Power Parity nor the Balassa/Samuelson hypothesis has explanatory value

An inspection of figure 1 and table 1 leads to the following conclusions. First: the PPP hypothesis is rejected. The real exchange rate does not revert to a constant mean. Instead, there is a significant trend appreciation of the real exchange rate in the transition economies. Second: it is not possible to rescue the PPP hypothesis by stating that the equilibrium real exchange rate for "tradable" goods $\mathrm{R}_{\mathrm{T}}$ is constant but that the $\mathrm{R}_{\mathrm{NT}}$ the relative price of non-traded/traded goods has been responsible for the appreciation of the real exchange rate.

The B/S effect hypothesis can be stated as follows ${ }^{6}$. The logarithm of the real exchange rate based upon the CPI index R(CPI) is defined to be equal to the logarithm of the real exchange rate of traded goods $R_{T}$ plus the $R_{N T}$, a weighted logarithm of the relative price of non-traded to traded goods at home and abroad. $\mathrm{R}(\mathrm{CPI})=\mathrm{R}_{\mathrm{T}}+\mathrm{R}_{\mathrm{NT}}$

The GDP is supposed to be divided into tradable goods, where the law of one price prevails, and non-tradable goods where there is no law of one price. The law of one

\footnotetext{
${ }^{6}$ See chapter seven part 1.4 for a discussion of the role of the B/S effect in the euro area.
} 
price for tradables means that $\mathrm{R}_{\mathrm{T}}$ is a constant. By definition, there is no law of one price for nontradables. Therefore variations in the real exchange rate R(CPI) are determined by variations in $\mathrm{R}_{\mathrm{NT}}$ relative prices non-tradable/tradable in the two countries.

Empirical studies testing this hypothesis are arbitrary because it is not clear what are tradable and non-tradable goods. Arbitrary proxies are used to estimate $\mathrm{R}_{\mathrm{NT}}$, whose meaning is ambiguous. Authors differ in what they include in traded or non-traded goods ${ }^{7}$, which lead to significant differences in the empirical results. Some assume that $\mathrm{R}_{\mathrm{NT}}$ can be proxied by the ratio of the CPI/WPI. Several authors state that the producer price index PPI does not include prices in the services sectors, whereas the CPI index includes services. They ${ }^{8}$ then argue that the real exchange rate based upon the producer price index $\mathrm{R}(\mathrm{PPI})$ reflects the $\mathrm{R}_{\mathrm{T}}$ the relative price of traded goods, and that the difference between the real exchange rate based upon the CPI index and R(PPI) the real exchange rate based upon the PPI index reflects the relative price of non-traded/traded goods, $\mathrm{R}_{\mathrm{NT}}=[\mathrm{R}(\mathrm{CPI})-\mathrm{R}(\mathrm{PPI})]$. The econometric results vary drastically depending upon the measures used for "tradable/nontradable" goods ${ }^{9}$.

One estimate of the significance of the B/S hypothesis - as stated in the paragraph above - is that the percentage change $\Delta \mathrm{R}(\mathrm{PPI})$ is negligible - the "law of one price" prevails for "traded" goods - and that the variation in the real exchange rate arises from variations in the relative price of non-traded/traded goods $\Delta[\mathrm{R}(\mathrm{CPI})$ - R(PPI)].

Operationally the $\mathrm{B} / \mathrm{S}$ states that the ratio of $\Delta \mathrm{R}(\mathrm{PPI})$ to $\Delta[\mathrm{R}(\mathrm{CPI})-\mathrm{R}(\mathrm{PPI})]$ is small. Let $\varepsilon$ be the ratio of $\Delta \mathrm{R}(\mathrm{PPI})$ to $\Delta[\mathrm{R}(\mathrm{CPI})]$. The $\mathrm{B} / \mathrm{S}$ hypothesis can be expressed as equation (1) in percent change $(\Delta R)$, where the hypothesized ratio $\varepsilon$ is "small".

(1) $\Delta \mathrm{R}(\mathrm{PPI}) / \Delta \mathrm{R}(\mathrm{CPI})=\varepsilon \sim 0$

Table 1 shows that neither PPP nor the B/S hypothesis has explanatory value. Columns 1 and 2 show the appreciation of both R(CPI) and R(PPI) over the transition period 1991to 2004 and from 1995-2004 in each country. Table 1/column 3 shows that the value of $\varepsilon$ is large. For the period 1995-2004, the main part of the variation in the CPI real exchange rate comes from the real exchange rate based upon the PPI index. Epsilon $\varepsilon$

\footnotetext{
${ }^{7}$ See Egert, Hapern and MacDonald, table 8 for a list of how various authors arbitrarily classify open/closed, tradable/nontradable sectors in transition economies.

${ }^{8}$ See the discussions in Egert, Halpern and MacDonald, and in Lommatzsch and Tober.

${ }^{9}$ See for example chapter $7 /$ table 2 .
} 
is $80 \%$ for Czech Republic, 66\% for Hungary and 64\% for Poland, whereas the B-S hypothesis claims that $\varepsilon$ is close to zero.

Table 1

Percentage change $(\Delta)$ in $\mathrm{R}(\mathrm{CPI})$ and $\mathrm{R}(\mathrm{PPI})=\mathrm{Np} / \mathrm{p}^{*}$, Czech Republic, Hungary, Poland, relative to Germany until 1999, then to Euro. Real R or Nominal appreciation is (+). Foreign producer prices $\mathrm{P}^{*}$ are those Germany.

\begin{tabular}{|l|l|l|l|l|}
\hline & Appreciation + & $(1)$ & $\begin{array}{l}(2) \\
\Delta \mathrm{R}(\mathrm{PPI})\end{array}$ & $\begin{array}{l}(3) \varepsilon= \\
\mathrm{R}(\mathrm{PPI}) / \Delta \mathrm{R}(\mathrm{CPI})\end{array}$ \\
\hline $\begin{array}{l}\text { Czech } \\
\text { Republic }\end{array}$ & $1991-2004$ & $51.6 \%$ & $42.6 \%$ & $83 \%$ \\
\hline CZ & $1995-2004$ & 34.5 & 27.6 & 80 \\
\hline Hungary & $1991-2004$ & 37.9 & 14.7 & 39 \\
\hline HU & $1995-2004$ & 35.8 & 23.7 & 66 \\
\hline Poland & $1991-2004$ & 31.7 & 14.9 & 47 \\
\hline PL & $1995-2004$ & 23.3 & 14.8 & 64 \\
\hline
\end{tabular}

Source: Lommatzsch and Tober (2005) spreadsheets, based upon International Monetary Fund data.

More direct tests of the B/S and PPP hypotheses are discussed in connection with the studies based upon panel data, summarized in table 2 below. In all cases, not only are the PPP and B/S hypotheses lacking in explanatory value, they are also theoretically deficient.

Suppose that the "law of one price" were valid. Let there be a significant rise in unit labor costs in the country relative to the rest of the world in all sectors of the economy. Then marginal costs are rising relative to both the internal and the external prices. The country would be losing competitiveness and the volume of exports would fall drastically, even though the law of one price prevails. The B/S and PPP hypotheses would not provide any early warning signals of an impending currency crisis. These hypotheses says nothing about the sustainability of the nominal exchange rate.

The theoretical deficiencies stem from the simplistic characterization of an economy: an arbitrary dichotomy between "traded" and "nontraded" goods, a law of one 
price for traded goods, no theory of a transmission process between total factor productivity and the trade balance, and no equation for balance of payments equilibrium. The $\mathrm{B} / \mathrm{S}$ equation is not a substitute for an explicit testable and operational model of exchange rate determination.

Another important characteristic of the transition economies, stressed especially by Lommatzsch and Tober (2005), concerns the trends in the current account and trade deficits in the Czech Republic, Hungary and Poland. The appreciations of the PPI real exchange rates of the accession countries have not been accompanied by a loss of competitiveness. Current account deficits have not continually increased with the appreciation of the R(PPI). In some countries, current account deficits have declined. Moreover, both exports and imports have grown in real as well as in nominal terms along with the appreciation of the R(PPI) exchange rate.

A third characteristic over the period 1993q1 - 2004 q4 is that labor productivity in industry or in the overall economy has been found to be the most stable determinant of the real exchange rate ${ }^{10}$. It makes very little difference whether the real exchange rate is $\mathrm{R}(\mathrm{CPI})$ or $\mathrm{R}(\mathrm{PPI})$.

The characteristics of the transition economies described above are inconsistent with the PPP and B/S methods of analysis. At best these two hypotheses cannot be used to answer the questions marked in bullets above.

\subsection{Organization of chapter}

The very large number of studies of the determinants of the equilibrium real exchange use the same, or a very similar, econometric methodology. They consider a vector $(\mathrm{R}, \mathrm{Z})$ of variables, in the real exchange rate $\mathrm{R}$ and a vector of candidate variables Z. Insofar as the real exchange rate is not stationary, they ask if the Z's are also nonstationary. A stationary variable is one that reverts to a constant mean. When they find a set of non-stationary variables, they use the standard econometric tests to see if they are cointegrated. Is there is a linear combination that is stationary? The stationary linear combination is called the cointegrating equation, which is interpreted as a long-run

\footnotetext{
${ }^{10}$ Égert and Lommatzsch.
} 
equilibrium relation among the variables ${ }^{11}$. They are just eclectic-econometric studies, and that is why the results differ among studies. Moreover, they cannot be used for policy analysis since they are not based upon an explicit and consistent theory. They cannot answer the questions marked with bullets at the beginning of this chapter.

Our approach is not to survey the extensive work that has been done ${ }^{12}$. Instead we use the NATREX model to explain the results of several key studies of the transition economies. There are several problems involved in trying to estimate the equilibrium real exchange rate of the CEEC/transition economies compared to what has been done for the synthetic euro. First, the time span of data for the post Socialism period is short.

Generally it is from 1991 or 1995 to the 2001. The use of Vector Error Correction Model (VECM) to find a long-run relation is questionable for a short period where the structure is changing. Second, several authors try to overcome the problem of the short period by using panel data of a set of countries over the post Socialism period. The problem of interpretation of panel data is that the estimation of coefficients such as $\mathrm{dR} / \mathrm{dZ}$ assumes that they are the same for each country - even though it is agreed that the countries are very different in their structure. Econometric results from panel data vary according to which countries are or are not included. The conclusion must be that one cannot place too much confidence in quantitative estimates of "the equilibrium" exchange rate, using just one method of estimation. Our approach here is to examine the studies, which use both approaches. To what extent can the NATREX model explain the econometric results? Part 4 of this chapter concludes by explaining what are the implications for policy.

The first set of studies that we consider are by Christoph Fischer/Bundesbank, and are based upon panel analysis. The methodology and results are discussed in part 2. In part 3, we interpret the panel results on the basis of the NATREX model. Then we draw upon several studies that are more country specific, written by economists at the Central Banks $^{13}$. The study of Hungary by Peter Karadi/Central Bank of Hungary is based upon the structural estimation of the NATREX model, similar to what Detken and Marin did for the synthetic euro discussed in chapter 7. The study of the Czech Republic by Jan

\footnotetext{
${ }^{11}$ See the discussion in chapter 7 section 3.

${ }^{12}$ See the detailed survey article by Égert, Halpern and MacDonald for a discussion of the extensive literature.

${ }^{13}$ The disclaimer is that the authors who are at the Central Banks are not expressing official views of their respective banks.
} 
Frait and Lubos Komarek uses the reduced form dynamics VECM approach. The study by Lommatzsch and Tober concerning several transition economies focuses upon the crucial trade balance structural equation. The conclusions, the answers to the questions in bullets, are in part 4 , the policy implications.

\section{Econometric Analysis based upon Panel data ${ }^{14}$}

Christoph Fischer addressed the question concerning what factors might have caused trend appreciations of the real effective exchange rates of the transition economies. He used panel methods for the estimation, because the observation period may be too short to obtain reliable estimates of the long-run effects of economic variables upon market determined equilibrium real exchange rates in the transition economies. The panel initially consisted of ten CEEC, which have been in the process of entry into the EU. The question concerning the equilibrium real exchange rate is important because these countries would enter the Euro area in the foreseeable future. In one set of estimations, he used 10 countries. Due to their heterogeneity, the econometric panel results were significantly changed when Romania and Bulgaria were excluded. Panel data tests are sensitive to the set of countries included or excluded. The data reported in table 2 below consists of the eight countries cited at the foot of the table .

The variables selected for panel analysis of equilibrium real exchange rates were not arbitrary. First, he tested carefully the Balassa/Samuelson hypothesis that sectoral relative prices $R_{N T}$ can account for the trends in the real effective exchange rate. Sectoral measures of productivity were included in his regressions. Second, total labor productivity or total factor productivity and measures of social consumption were also used. These variables play important roles in the NATREX model. ${ }^{15}$

\footnotetext{
${ }^{14}$ This section is based upon two articles: Christoph Fischer, July 2002; Bundesbank/Fischer, October 2002.

${ }^{15}$ Fischer is quite familiar with the NATREX model, which was used by Fischer and Sauernheimer in their study of exchange rates in Germany. That explains his choice of variables. His studies are not data mining.
} 
Table 2

PANEL DATA. Determinants of the real effective exchange rate in central and eastern European accession countries*. Period:1994-99. Rise is an appreciation.

\begin{tabular}{|c|c|c|c|c|c|}
\hline $\begin{array}{l}\text { Explanatory } \\
\text { variable }\end{array}$ & $\begin{array}{l}\text { Estimation } \\
\text { A } \\
\text { Coefficient } \\
\text { (t-stat) }\end{array}$ & $\begin{array}{l}\text { Estimation } \\
\text { B } \\
\text { Coefficient } \\
\text { (t-stat) }\end{array}$ & $\begin{array}{l}\text { Estimation } \\
\mathrm{C} \\
\text { Coefficient } \\
\text { (t-stat) }\end{array}$ & $\begin{array}{l}\text { Estimation } \\
\text { D } \\
\text { Coefficient } \\
\text { (t-stat) }\end{array}$ & $\begin{array}{l}\text { Estimation } \\
\text { E } \\
\text { Coefficient } \\
\text { (t-stat) }\end{array}$ \\
\hline $\begin{array}{l}\text { Labor productivity } \\
\text { in agriculture }\end{array}$ & $0.46(2.87)$ & $0.44(3.64)$ & $0.55(3.24)$ & & \\
\hline $\begin{array}{l}\text { Labor productivity } \\
\text { in industry }\end{array}$ & $0.76(3.34)$ & $0.60(2.65)$ & 1.65 (6.07) & & \\
\hline $\begin{array}{l}\text { Labor productivity } \\
\text { in services }\end{array}$ & & & $0.9(2.06)$ & & \\
\hline $\begin{array}{l}\text { Total labor } \\
\text { productivity }\end{array}$ & & & & $\begin{array}{l}1.68 \\
(17.49)\end{array}$ & $\begin{array}{l}1.58 \\
(15.81)\end{array}$ \\
\hline Consumption/GDP & $0.89(4.13)$ & --- & $1.82(3.75)$ & $0.55(3.98)$ & --- \\
\hline $\begin{array}{l}\text { Government } \\
\text { consumption/GDP }\end{array}$ & ------- & $0.45(3.51)$ & & & 0.24 (3.39) \\
\hline $\begin{array}{l}\text { Real rate of interest } \\
\text { (average of USA } \\
\text { and Germany) }\end{array}$ & $\begin{array}{l}-0.21(- \\
4.18)\end{array}$ & $-0.23(-4.2)$ & $0.08(2.5)$ & $\begin{array}{l}-0.03 \\
(-2.77)\end{array}$ & $\begin{array}{l}-0.04 \\
(-3.52)\end{array}$ \\
\hline
\end{tabular}

Sources: Deutsche Bundesbank/Christoph Fischer, Monthly Report, July 2002, and Fischer, Deutsche Bundesbank Discussion Paper 19/02,table 2. Estimations (A)(B)(C) are based upon annual data 1994-99; and estimations (D)(E) are based upon quarterly data 1994:1 - 2000:4, p 58. Data, except for interest rates, are in logarithms of variables relative to a weighted average of OECD trading partners. *Czech Republic, Estonia, Hungary, Latvia, Lithuania, Poland, Slovak Republic and Slovenia.

The real effective exchange rate, social consumption/GDP, labor productivity are measured against a weighted average of the OECD trading partners of each country, and are expressed as logarithms. The external real interest rate is a simple average of Germany and the U.S. 
Table 2 summarizes the econometric results from panel data. Estimations (A) (B) and (C) are based upon annual data. The annual frequency of sectoral productivity data has been the main reason for using annual instead of quarterly data.

One sees that the signs of the estimated coefficients of sectoral productivity variables did not depend on the sector. Productivity increases in each sector caused a real appreciation although, in the case of the services sector, the coefficient was often insignificant. An increase in labor productivity in agriculture appreciates the real exchange rate just as does an increase in productivity in the industrial sector.

The three sectoral productivity variables were then replaced by one aggregated labor productivity series, which is GDP/number of employees in the whole economy. The proposed relationship was then estimated with a panel of quarterly data in the estimations in columns (D) and (E). The results are that: the real exchange rate is positively related to total labor productivity in the entire economy, and to the ratio of social consumption/GDP and is negatively related to the relative real rate of interest.

\section{NATREX explanation of the econometric studies of the transition economies}

Fischer's analysis of panel data in table 2, and the country studies especially of Hungary by Karadi and of the Czech Republic by Frait and Komarek discussed below, can be understood on the basis of the NATREX model. We also show how other studies such as by Lommatzsch and Tober and those surveyed by Egert, Halpern and MacDonald can be interpreted in this framework.

The NATREX model, developed in chapter 4 and applied to the euro area in chapter 7 , concerns the equilibrium rate. This is where the rate is heading. It is a sustainable rate and is not the actual rate at any one time. In the medium-run, it is associated with internal equilibrium - where the rate of capacity utilization is at its stationary mean and there are no inflationary or deflationary pressures - and also external equilibrium where real long-term interest rates are equal to the foreign rates. The debt/GDP ratio and the growth rate are predetermined in the medium-run. The economy travels along a trajectory where these two variables stabilize at their long-term values. The long-run equilibrium is the limit of medium-run equilibria, and is a function of a time varying vector of fundamentals denoted $\mathrm{Z}_{\mathrm{t}}$. Insofar as this vector changes, so do the 
medium-run and long-run equilibria. This implies that misalignment will occur if the nominal exchange rate and relative prices cannot adjust to the changing equilibrium.

We summarize ${ }^{16}$ in BOX 1 and graph in figures 2 - 4 the implications of the NATREX model that are relevant for the transition economies. There are three real fundamentals: (i) Relative ${ }^{17}$ time preference $\delta / \delta *$, which is the ratio of social consumption/GDP, (ii) Relative productivity ${ }^{18}$ in the whole economy, which is either total factor productivity or total labor productivity y/y*, (iii) Growth rate g. Endogenous variables are: the real exchange rate $\mathrm{R}$ and the debt ratio $\mathrm{F}$, defined as the negative of the net investment position/GDP. The net investment position includes equity as well as debt.

\section{BOX 1}

SUMMARY NATREX MODEL: Medium-run and long-run effects

\begin{tabular}{|l|l|l|l|}
\hline $\begin{array}{l}\text { Disturbance: changes in } \\
\text { fundamentals }\end{array}$ & $\begin{array}{l}\text { Medium-run real } \\
\text { Exchange rate } \mathrm{R}, \\
\text { debt ratio given }\end{array}$ & $\begin{array}{l}\text { Long-run real } \\
\text { exchange } \\
\text { rate } \mathrm{R}^{*}\end{array}$ & $\begin{array}{l}\text { Long-run } \\
\text { debt-ratio F }\end{array}$ \\
\hline $\begin{array}{l}\Delta(\mathrm{I}-\mathrm{S}) \\
\text { rise in investment less saving, } \\
\text { rise in time preference } \delta\end{array}$ & Appreciate & depreciate \\
\hline $\begin{array}{l}\Delta \mathrm{Z}_{\mathrm{B}} \\
\text { Rise in trade balance } \\
\text { Function, rise in productivity y }\end{array}$ & Appreciate & Increases \\
\hline $\begin{array}{l}\Delta \text { g, when } \mathrm{F}(0)>0 \\
\text { Rise in growth rate }\end{array}$ & 0 & appreciate & decreases \\
\hline
\end{tabular}

See chapter 4, box 3. Figures 3 and 4 below summarize this table.

Figure 2 describes the medium-run effects ${ }^{19}$. The medium-run equilibrium real exchange rate equilibrates saving less investment - the SI curve - to the current account -

\footnotetext{
${ }^{16}$ See chapter 4 for technical details.

${ }^{17}$ Foreign variables are denoted by asterisks.

18 The effects of variations in the terms of trade are understood in terms of the productivity variable.

${ }^{19}$ See chapter 4 part 4 for details.
} 
the CA curve. The current account is the trade balance plus income transfers of interest plus dividends.

A rise in time preference $\delta$ means a decline in social saving (public plus private). The SI curve shifts from SI(0) to SI(1). The decline in saving relative to investment induces a capital inflow $A d t$, which appreciates the real exchange rate from $\mathrm{R}(0)$ to $\mathrm{R}(1)$. Investment and growth are adversely affected by the appreciated real exchange rate. The resulting current account deficits $A d t$ produce the transfer of resources. The current account deficit is the rate of change of the debt. This means that, given the new saving and investment functions, a current account deficit raises the debt steadily. The CA curve keeps shifting steadily to the left, along the SI(1) curve, as the debt rises and exchange rate depreciates.

The growing current account deficit depresses the real exchange rate along the SI(1) curve, and the debt ratio rises steadily. This is a movement from $\mathrm{A}^{\prime}$ to $\mathrm{A} "$ ". In the stable case, the growth of the debt reduces net worth. In turn, consumption declines, saving rises, the SI curve then shifts to the right, and the debt ratio stabilizes at a higher value.

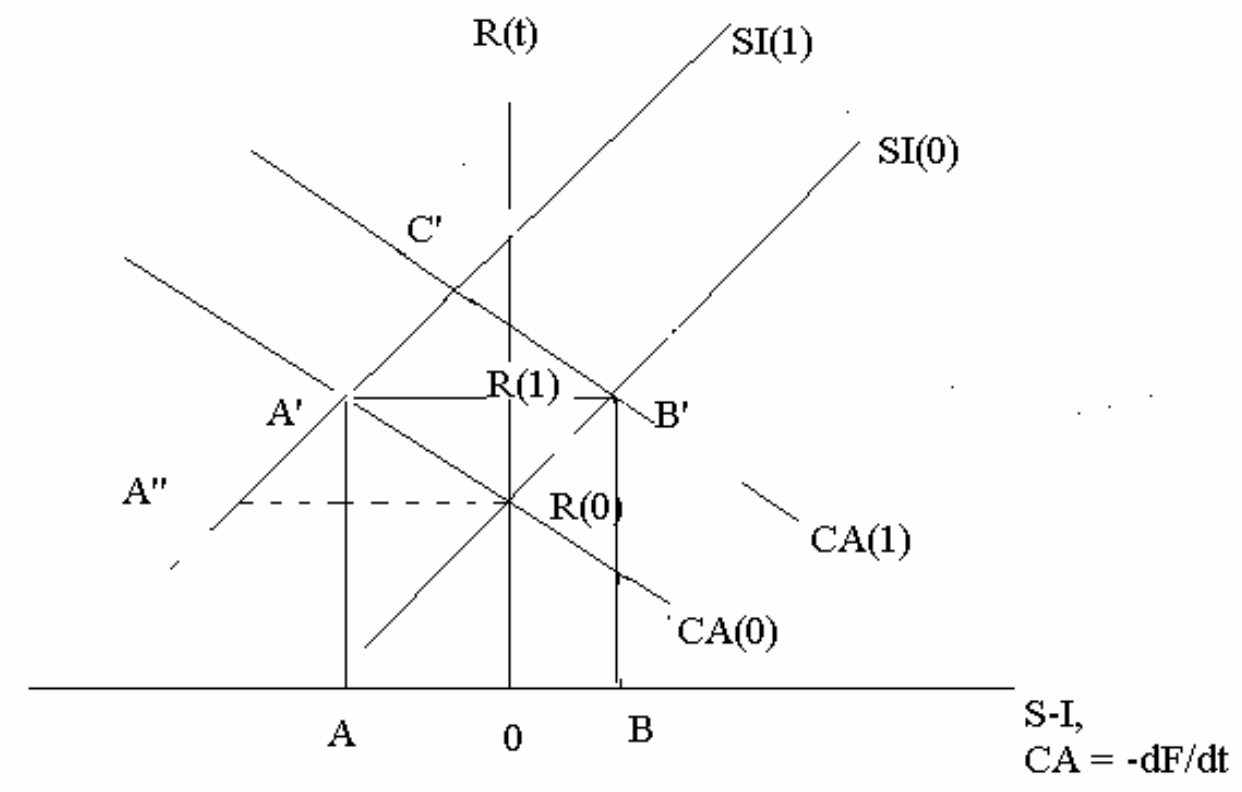

Medium run Equilibrium 
Figure 2. Medium-run NATREX resulting from a rise in time preference/decline in social saving rate $R(0)=>A^{\prime}$, a rise in the trade balance function $R(0)=>B^{\prime}$.

Figure 3 describes the dynamics of the convergence process in the case of table 2/row 1. Start with the exchange rate and the debt ratio at the origin. The real exchange $\mathrm{R}_{t}$ rate first appreciates from $\mathrm{R}(0)$ to $\mathrm{R}(1)$ in figure 2 , and the debt ratio $\mathrm{F}_{\mathrm{t}}$ rises. After a certain point, at time $\mathrm{t}=\mathrm{T}$, the rise in the interest payments on the $\mathrm{debt}^{20}$ and the lower growth rate lead to a decline (depreciation) in the real exchange rate to $\mathrm{R}^{*}$, which is below its initial level. The trajectory of the real exchange rate is not monotonic, but the debt rises monotonically to $\mathrm{F}^{*}$ a new long-run equilibrium.

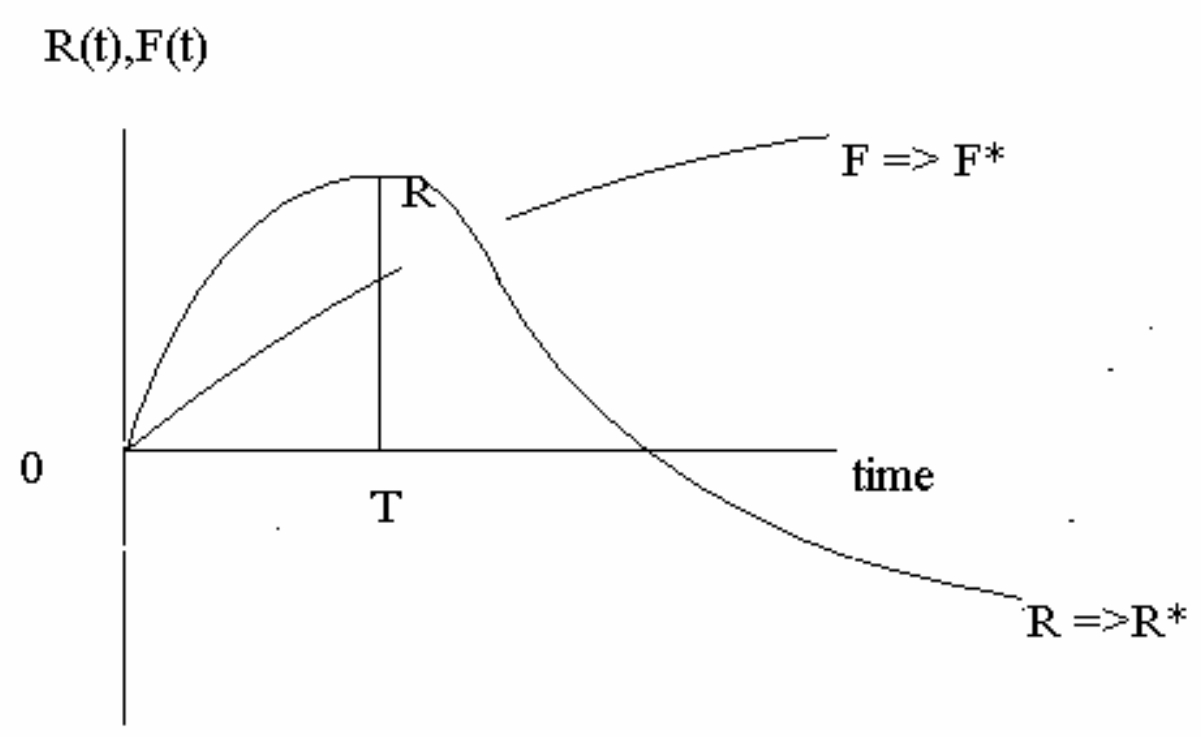

\section{Initial increase (I-S), rise in time preference or investment demand}

Figure 3. Dynamic effects of a decline in social saving/rise in social consumption, or a rise in investment, upon the trajectories of the real exchange rate $R_{t}$ and $F_{t}$ the debt/GDP ratio. Other parameters are assumed to be fixed. Long-run values are $\mathrm{R}^{*}, \mathrm{~F}^{*}$.

The second effect concerns parameter $\mathrm{Z}_{\mathrm{B}}$ in the trade balance $\mathrm{B}=\mathrm{B}\left(\mathrm{R} ; \mathrm{Z}_{\mathrm{B}}\right)$, which reflects the factors that change the trade balance function at any given real exchange rate.

\footnotetext{
${ }^{20}$ Debt includes portfolio plus direct investment, so interest includes the payment of dividiends.
} 
This is graphed as shifts in the current account function CA in figure 2. Specifically, let there be foreign direct investment FDI in the economy. The first effect is that investment rises relative to saving. The SI curve shifts to the left from SI(0) to SI(1). The mediumrun effect is just like the decline in social saving graphed in figure 2 . The capital inflow appreciates the real exchange rate and produces a current account deficit. The debt rises for a while.

Unlike the case of a decline in saving/rise in time preference, the FDI is induced by a privatization and liberalization of the economy. There are unexploited opportunities for productive investment. Investment is productive if the q-ratio exceeds unity, the expected marginal return exceeds the opportunity cost. Under Socialism, such an economic calculus did not influence investment decisions; and the quality of products was low. With privatization and liberalization there is a marked shift from low quality, low value-added products towards products of higher quality and value added ${ }^{21}$. That is, investment occurs in sectors where the q-ratio exceeds unity.

A graphic microeconomic description of the process, underlying the macroeconomic analysis of FDI is as follows. The productivity in the entire economy, GDP per worker or total factor productivity, affects the marginal cost of producing goods that can be exported relative to demand. Marginal cost is the ratio of nominal input prices divided by the marginal productivity. In figure 4, the demand function is D and the shortrun marginal cost functions are labeled SM. The short run marginal cost function depends upon the input prices and the current level of productivity of the inputs that are variable in the short-run, but the quantity of "capital" is given. The long-run marginal cost function $\mathrm{L}(\mathrm{y})$ is derived when "capital" is variable and the marginal cost of production is the same for all inputs. When the short-run marginal cost is SM1, optimal output is X1. But short-run marginal cost at that point exceeds long-run marginal cost. This means that there is a less than optimal quantity of "capital" - the factor that is relatively fixed in the short-run. Alternatively it means that the marginal return to investment is greater than the opportunity cost, the q-ratio exceeds unity.

Foreign direct investment FDI may be induced because short-run marginal cost exceeds long-run marginal cost. That is, FDI is induced because more capital will be

\footnotetext{
${ }^{21}$ This theme is stressed by Lommatzsch and Tober.
} 
productive. The decline in short-run marginal costs occurs when productivity rises relative to nominal factor prices. For example, there may be a decline in the prices of services, an improved domestic transportation system, improved telecommunications, or better IT. Productivity rises with FDI as shown in equation (3). This means that short-run marginal cost declines from SM1 to SM2. The cost of producing quantity X1 of output declines. It is optimal to expand the value of output. But "output" has a quality as well as a quantity dimension. The expansion of output to X2 could mean that the quality of output X2 is superior to that of X1. With the lower level of productivity SM1, only the low quality output was profitable. With the higher level of productivity induced by FDI, the short run marginal cost declines to SM2 and a higher quality X2 is profitable. The shifting of the short-run marginal cost function, resulting from the rise in productivity, corresponds to an increase in $\mathrm{Z}_{\mathrm{B}}$ in the trade balance function. These developments are subsumed under parameter $Z_{\mathrm{B}}$ in the trade balance function.

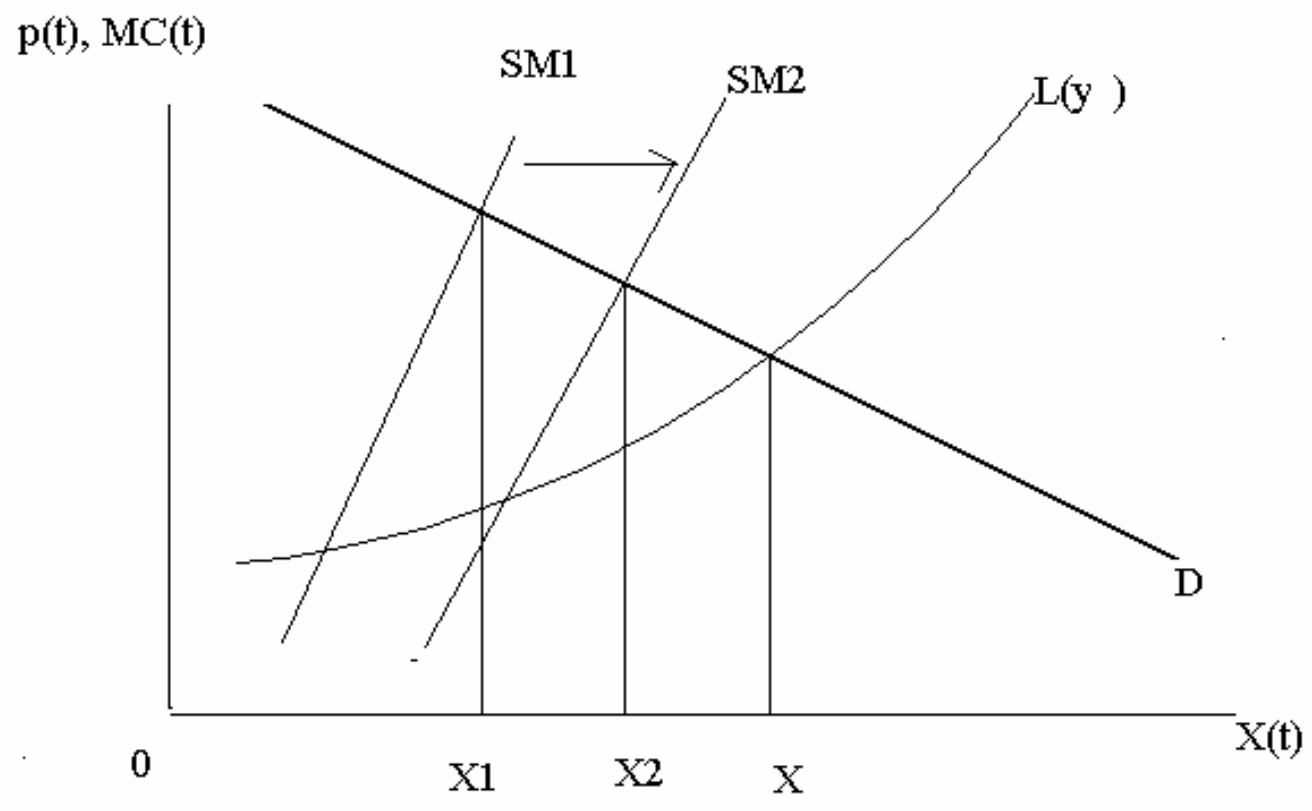

Figure 4. Optimal output is affected by FDI that lowers short-run marginal cost. Output has both a qualitative as well as a quantitative dimension. 
The productive investment leads to capital inflows, a current account deficit and a change in the composition of the GDP. The improved allocation of resources has two effects. First: the growth rate of the economy rises. Second, productivity of the economy increases and parameter $\mathrm{Z}_{\mathrm{B}}$ in the trade trade balance function rises.

The macroeconomic interpretation of the effect of FDI is summarized in the last two rows of BOX 1. Formally, the growth rate of the economy $(1 / \mathrm{Y}) \mathrm{dY} / \mathrm{dt}$ is equation (2), based upon chapter 4 section (3.4). The GDP is Y. The first term is the productivity of investment $b_{t}$ times the ratio $I_{t}$ of investment/GDP. The second term $Z_{g}$ is the growth of employment plus the effects of an improved allocation of resources. The latter involves shifting resources from uses where the value of the marginal product is low to where it is high, based upon market-determined prices. These are structural changes from lower to higher quality and value added uses.

(2) $g_{t}=(1 / Y) d Y / d t=b_{t} I_{t}+Z_{g}$ Solve (2) for the GDP and derive equation (3) for the productivity of the economy $y(t)=$ $\mathrm{Y}(\mathrm{t})$ /worker. The initial labor productivity is $\mathrm{y}(0)$.

(3) $y(t) / y(0)=\exp \left[\int^{t} b_{s} I_{s} d s+z . t\right]$

The productivity of the economy is an integral of the productivity of investment times the investment ratio over a period of years. The second term $\mathrm{z}$ reflects the average annual value of $Z_{g}$. Foreign Direct Investment affects $b_{s} I_{s}$ the productivity of the investment undertaken times the investment ratio. Thereby the FDI and improved resource allocation lead to the build-up of productivity over a period of years. It is this productivity of the economy that increases the trade balance function $B\left(R ; Z_{B}\right)$ and the growth rate of the economy.

Graphically the CA function in figure 2 gradually shifts to the right from CA(0) to $\mathrm{CA}(1)$ as productivity rises. At any given real exchange rate, the trade balance increases, and the debt ratio declines. The trajectories of the real exchange rate and the debt ratio are described in figure 5.

The net effect of FDI is a combination of figures 3,4 and 5. Initially, the real exchange rate appreciates, there are current account deficits and the debt rises. Later on, as the productivity effect in equation (3) grows, the growth rate rises, the economy is 
more competitive, the current account function shifts to the right, the debt ratio declines and the real exchange rate appreciates.

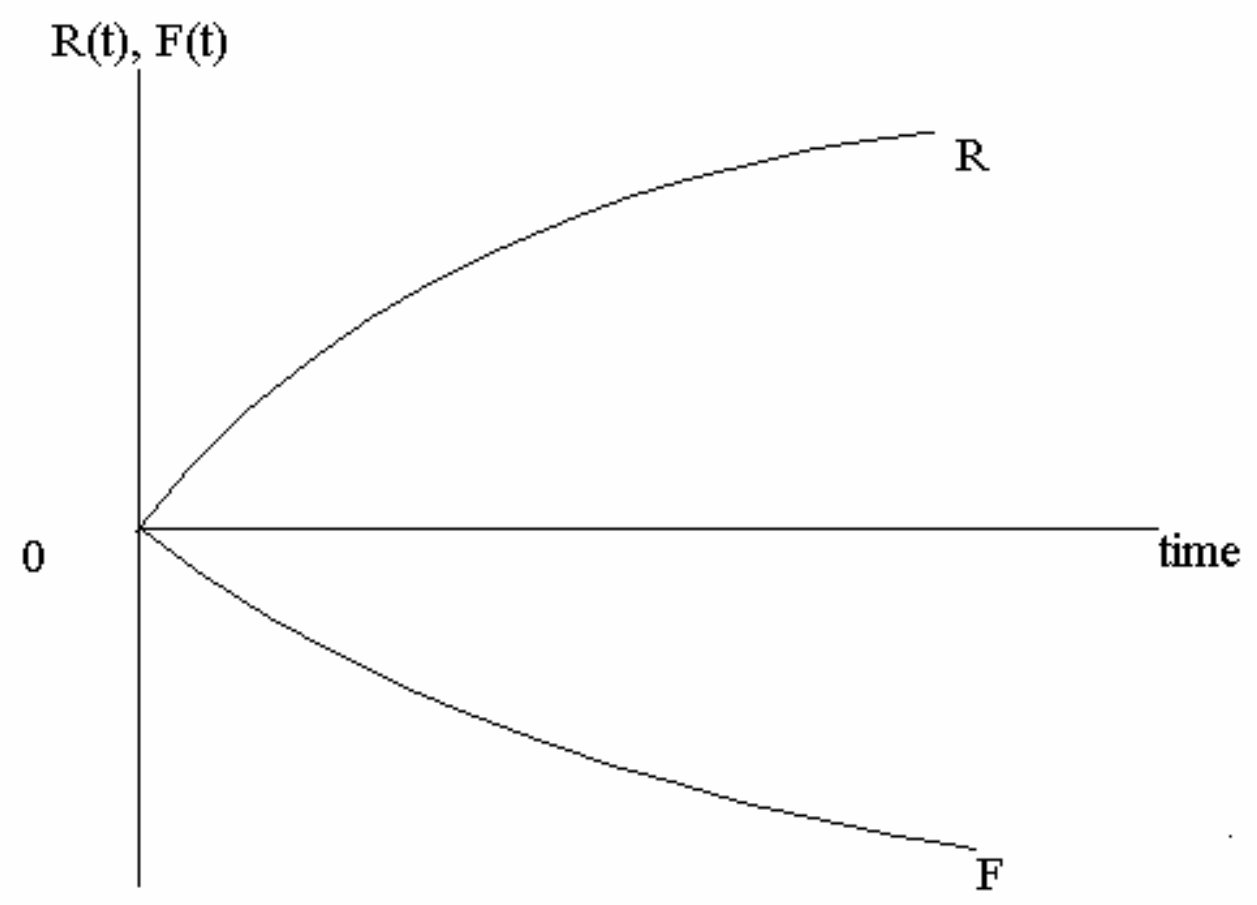

Increase trade balance function $B(R ; Z)$ and/or Growth

Figure 5. Foreign direct investment induced by the productivity of investment raises productivity according to equation (3). The current account function CA in figure 2 shifts to the right. There is long-run exchange rate appreciation and a decline in the debt ratio.

Figures 2 - 5 are graphic representations of the conclusions of the NATREX model in BOX 1, based upon chapter 4. These figures are extremely important, because they explain why many results from the eclectic-econometric approaches can be ambiguous and misleading $^{22}$. On the basis of the analysis above we analyze and evaluate some key empirical studies of the transition economies.

\footnotetext{
${ }^{22}$ See Égert, Halpern and MacDonald, table 5 for the ambiguous results of the various studies.
} 


\subsection{Interpretation of results from panel data}

There are two main results from table 2 based upon panel data. First: the real exchange rate appreciates with a growth in productivity. It is the growth in total labor productivity that is relevant, regardless of the sector where it occurs. Second: the real exchange rate is positively related to the relative consumption ratio.

The first effect is explained by relating total labor productivity to the liberalization of the economy, a rise in productive investment and an improved allocation of resources. Initially, FDI finances productive investment, and shifts the SI function in figure 2 to the left from SI(0) to SI(1). The exchange rate appreciates and induces a current account deficit, which finances the excess of investment less saving. In the medium run the economy is at point $\mathrm{A}^{\prime}$ in figure 2 .

The growth of the "debt", the decline in the net investment position, does imply that there will be a future transfer of interest and dividends. People who look at the current account deficit A dt in figure 2 at point A' may feel that this augurs a depreciation of the exchange rate in the future. This is myopic thinking because it fails to see the difference between the effects of a decline in social saving and a rise in productive investment. The difference is as follows.

The integral of investment times the productivity of investment is productivity at time $t, y(t)=y(0) \exp \left[\int^{t} b_{s} I_{s} d s+z . t\right]$. As a result of the FDI, the CA function shifts gradually to the right from $\mathrm{CA}(0)$ to $\mathrm{CA}(1)$. The trajectories of the real exchange rate and the debt ratio are that: at first the rise in investment produces the graphs in figure 3 . In the longer-run as productivity rises, the real exchange rate appreciates and debt ratio declines (the net investment position increases) as described by figure 5. This is an important implication of NATREX analysis.

The study by Lommatzsch and Tober (L-T) can be related to that of Fischer summarized in table 2. They found that: (L-T:1) both the CPI and PPI real exchange rates of the accession countries have been appreciating since macroeconomic stabilization was achieved. This result, along with the results of the panel study of Fischer, cannot be explained by the PPP and the B/S hypotheses.

(L-T:2) The appreciation has not been accompanied by a loss of competitiveness. There has not been a corresponding steady decline in the trade balance/GDP and current 
account/GDP functions. What has happened is consistent with the analysis summarized in the last two rows in BOX 1 where the rise in productivity has shifted the CA function to the right.

(L-T:3) The dominant factor has been an increase in $\mathrm{Z}_{\mathrm{B}}$ in the trade balance function $\mathrm{B}\left(\mathrm{R} ; \mathrm{Z}_{\mathrm{B}}\right)$. There has been an increase in the capacity to produce goods of higher quality and technological content: a catch-up factor. Most likely the improved allocation to higher value-added goods can show up as an improvement in the terms of trade. However in this case, the improved terms of trade are not exogenous ${ }^{23}$. The increase in total factor productivity corresponds to the scenario in the last two rows of BOX 1.

Lommatzsch and Tober focus upon the improved allocation of resources as an important factor explaining both the exchange rate and trade balance. They use two methods of estimation for the Czech Republic, Hungary and Poland. In the first, they estimate export and import equations using the real exchange rate R(PPI) using the PPI price deflators ${ }^{24}$, labor productivity in industry or in the entire economy, and foreign demand. This is a structural equation approach. The result is: (L-T:4) the productivity in industry can be regarded as the driving force behind exports, especially in Hungary and Poland. That means that productivity in the economy is the driving force in the $\mathrm{B}\left(\mathrm{R} ; \mathrm{Z}_{\mathrm{B}}\right)$ function. See BOX 1 row 2 and the analysis of shifts in the CA function above.

They then move on to a reduced form analysis. The equilibrium real exchange rates $\mathrm{R}(\mathrm{PPI})$ were calculated using variables that were earlier determined as affecting the current account: productivity differentials and external debt or net foreign assets. The medium-run equilibrium $\mathrm{R}$ equates the sum of the current account plus the capital inflows to zero. They found that: (L-T:5) in all countries, the productivity differential relative to Germany contributes to the real PPI based exchange rate. This result is consistent with the results from the estimated export equations.

The main conclusions are consistent with the NATREX model summarized in $\mathrm{BOX} 1$. A long-run appreciation of the real exchange rate requires that there be a rise in relative productivity in the entire economy that shifts the trade balance function $B\left(R ; Z_{B}\right)$ to the right. Then the appreciation of the real exchange rate is not accompanied by rising

\footnotetext{
${ }^{23}$ I owe this insight to Jan Frait.

24 The foreign country is Germany.
} 
current account deficits. In figure 2, when the CA function shifts from CA(0) to CA(1) the real exchange rate appreciates from $\mathrm{R}(0)$ to $\mathrm{R}(1)$ and the current account/GDP rises from 0 to $\mathrm{B}$ dt. Parameter $\mathrm{Z}_{\mathrm{B}}$ is associated with total productivity as described by the integral of the growth equation (3).

Figure 6 shows that the appreciation of the real exchange rate 1994-2004 (see figure 1) was not associated with deteriorating ratios of trade balance of goods and services/GDP. The trade or current account balance could result from the scenario in figure 3 either as a movement from $\mathrm{R}(0)$ to $\mathrm{A}^{\prime}$ or from $\mathrm{R}(0)$ to $\mathrm{B}$ '.

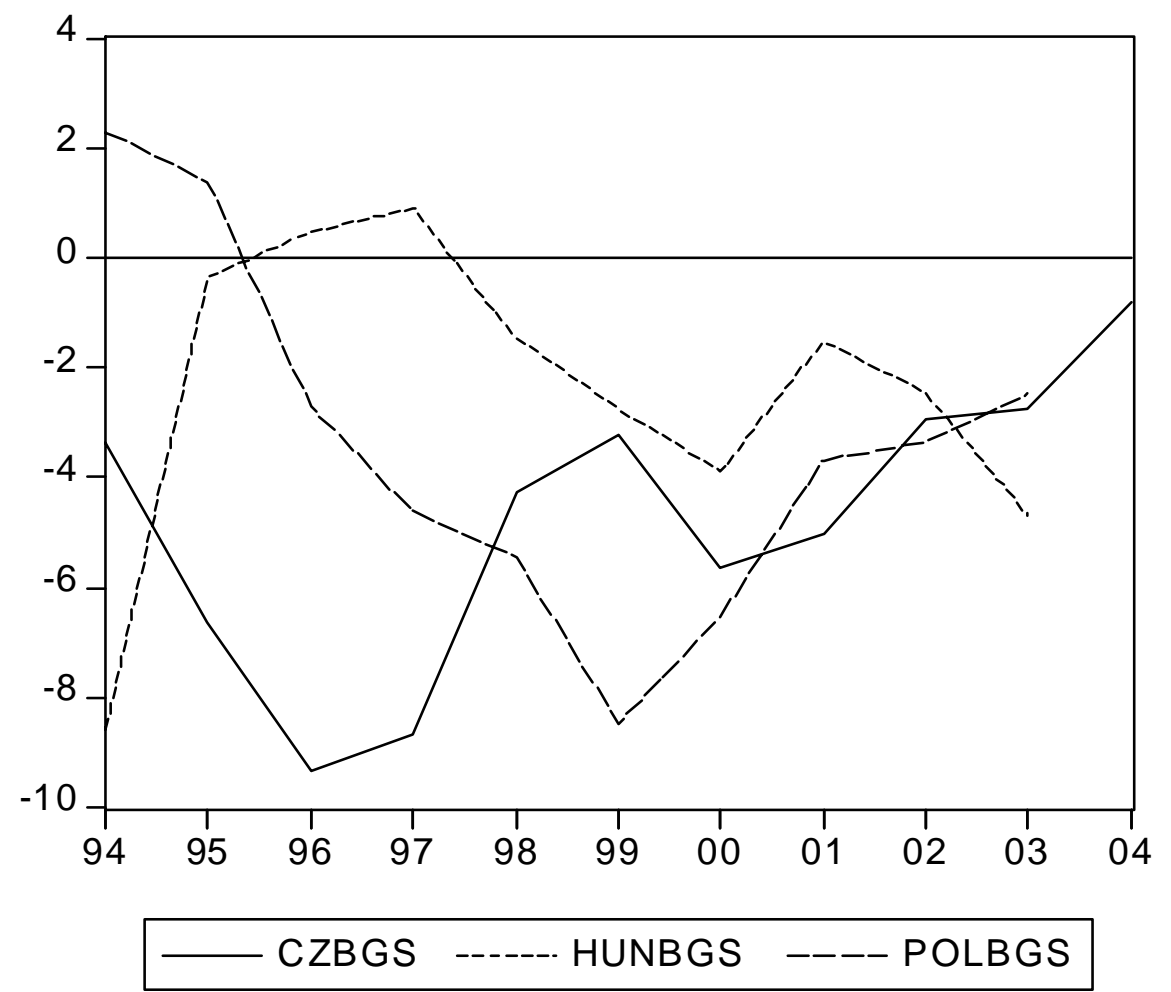

Figure 6. Balance goods and services/GDP, Czech Republic, Hungary and Poland Source: IMF data underlying article by Lommatzsch.

The second result in the panel table 3 is that a rise in consumption/GDP appreciates the real exchange rate. In the short-time span covered, one tends to see only the medium-run equilibrium. The rise in the consumption ratio corresponds to a rise in investment less saving, row 1 in BOX 1 . This corresponds to the leftward shift of the SI function in figure 3. The real exchange rate appreciates and there is a current account 
deficit. Graphically, this is described by the early part in figure 3 over the period $(0, T)$ where both the real exchange rate and the debt rise.

The observed relation between the real exchange rate and the debt ratio depends upon (i) the period considered such as $(0, T)$ or the longer period $(0, T+s)$, and (ii) the type of fundamental that has changed, the rows in BOX 1/figures 3 - 5. Simple eclecticeconometric analysis is not sensitive to these distinctions and hence often leads to ambiguous, bizarre or contradictory results.

Tests based upon panel data implicitly assume that the exogenous/control variables have the same effects upon the endogenous variables in each country. This is a questionable assumption, given the significant differences in their structures and development. Tests of long-run effects based upon data from each transition economy suffer from short sample period. Therefore, we evaluate both types of studies from the NATREX point of view.

We have explained the panel data results in terms of the NATREX model. Next, we turn to two country studies. The first country is Hungary. Peter Karadi estimated the structural equations of the NATREX model. The second is the Czech Republic, where Frait and Komarek used a reduced form estimation of the NATREX model. 
3.2 Hungary: Structural Equation estimation.

Peter Karadi of the Central Bank of Hungary ${ }^{25}$ estimated the equilibrium trajectory, and hence any misalignment, of the Hungarian real exchange rate using the NATREX approach. He stated that the "advantage of the NATREX approach vis-à-vis other methods is its well founded - dynamic general equilibrium- theoretical basis. It can produce forecasts of the medium-term NATREX equilibrium and of the long-term equilibrium". He followed the method used by Detken and Marin and used quarterly data 1994q1 - 2002q4. The object was first to estimate the components of the SI and CA curves in figure 2: the investment function, the consumption (saving) function and the current account function. The arguments of these functions are discussed in chapter 4. From these equations the medium-run equilibrium NATREX is obtained, which is the point of the intersection of the SI and CA curves in figure 2.

Investment/ potential GDP equation (4) is based upon inter-temporal optimization in a stochastic environment or upon the q-ratio ${ }^{26}$. The investment ratio I is positively related to: (i) the growth rate of total factor productivity $\alpha$, (ii) the productivity of capital $\mathrm{Q} / \mathrm{K}$; and is negatively related to (iii) the real rate of interest $\mathrm{r}$, and (iv) the real exchange rate $\mathrm{R}=\mathrm{Np} / \mathrm{p}^{*}$, where a rise is an appreciation. The signs of the hypothesized partial derivatives are noted in the functions.

(4) $\mathrm{I}=\mathrm{I}\left(\alpha^{+}, \mathrm{Q} / \mathrm{K}^{+}, \mathrm{r}^{-}, \mathrm{R}^{-}\right) \quad \mathrm{I}=$ Investment/ $\mathrm{Q}$ potential GDP

Social Consumption/potential GDP, C in equation (5), is derived from the intertemporal optimization in a stochastic environment ${ }^{27}$, where consumption depends upon net worth: capital less debt. Negative net foreign assets are net foreign debt. Saving is GDP less consumption.

(5) $\mathrm{C}=\mathrm{C}\left(\mathrm{K} / \mathrm{Q}^{+}, \mathrm{NFA} / \mathrm{Q}^{+}, \mathrm{PDI} / \mathrm{Q}^{+}, \mathrm{r}^{-}\right)$

The consumption ratio is positively related to: (i) capital/potential output K/Q, (ii) net foreign assets/potential output NFA/Q, (iii) personal disposable income/potential output PDI/Q. (iv) An increase in real interest rate r decreases consumption.

\footnotetext{
${ }^{25}$ The usual disclaimer applies. His paper does not represent the official view of the Bank.

${ }^{26}$ See chapter 4 section (3.2).

${ }^{27}$ See chapter 4, section (3.1).
} 
The trade balance equation (6) is based upon the optimization of firms ${ }^{28}$.

(6) $\mathrm{B}=\mathrm{B}\left(\mathrm{R}^{-}, \mathrm{ABS}^{-}, \mathrm{C}^{*}{ }^{+}\right) \quad$ Trade balance/potential GDP

An appreciation of real exchange rate $\mathrm{R}$ reduces trade balance. $\mathrm{A}$ rise in $\mathrm{ABS}=$ absorption/potential GDP reduces trade balance. A rise in foreign (German) consumption ratio $C^{*}$ increases the trade balance. The current account /potential GDP, denoted CA, is equal to trade balance B plus investment income r(NFA) = interest rate(net foreign assets/Q).

(7) $\mathrm{CA}=\mathrm{B}+\mathrm{r}(\mathrm{NFA})$.

To obtain the medium and long term NATREX, Karadi filtered all flow variables to eliminate the temporary effects. Estimated parameters in each structural equation have the hypothesized signs and residual tests support the hypothesis that the variables of each equation are cointegrated. Similar qualitative results are obtained from both the Engle-Granger and Phillips-Hansen methods.

Medium-run NATREX is the intersection of the SI and CA curves in figure 2. The medium-run NATREX is derived from solving equation (8), the intersection of the SI and CA curves ${ }^{29}$. The structural equation estimation of the medium-run NATREX is equation (9) derived from the estimates of equations (4)-(7).

(8) $\mathrm{C}(\mathrm{K} / \mathrm{Q}, \mathrm{NFA} / \mathrm{Q}, \mathrm{PDI}, \mathrm{r})+\mathrm{I}(\alpha, \mathrm{Q} / \mathrm{K}, \mathrm{r}, \mathrm{R})+\mathrm{B}\left(\mathrm{R}, \mathrm{ABS}, \mathrm{C}^{*}\right)+\mathrm{r}(\mathrm{NFA})=1$.

(9) $R_{t}=R\left(K_{t} / Q_{t}, N F A_{t} / Q_{t} ; Z_{t}\right)$. Medium-run NATREX

BOX 1 column "Medium-run" explains the NATREX analysis of the effects of vector $\mathrm{Z}=$ (time preference, parameters of the trade balance function) upon the mediumrun equilibrium exchange rate.

Variables $K_{t} / Q_{t}$, NFA $t / Q_{t}$ in equation (9) for the medium-run NATREX are endogenous in the long-run, and $\mathrm{Z}$ is a vector of the other variables in equations (4)-(6). In order to estimate the long-term NATREX, the long-run relative values of the endogenous ratios $K_{t} / Q_{t}, N F A_{t} / Q_{t}$ have to be determined. In the long-run equilibrium, three conditions must be satisfied ${ }^{30}$. There must be medium-run equilibrium as described by equation (8). The ratio of capital/potential output is constant. Capital grows at same

\footnotetext{
${ }^{28}$ See chapter 4, section (3.3).

${ }^{29}$ The SI curve is derived from the estimation of equations (4) and (5). The CA curve in (7) is derived from the estimation of equation (6).

${ }^{30}$ See chapter 4 Appendix A and B.
} 
rate as potential GDP, equation (10). Net foreign assets/potential output is constant. Net foreign assets should grow at the rate of potential output. Consequently, the ratio of current account/net foreign assets should be equal to the $g$ the growth rate.

(10) $\mathrm{I} / \mathrm{K}=\mathrm{g}=$ growth rate.

(11) $\mathrm{CA} / \mathrm{NFA}=\mathrm{g}=$ growth rate.

The growth rate was determined from the appropriate filtered GDP series. Using (9)-(11), the long-term NATREX is derived, $\mathrm{R}^{*}=\mathrm{R}(\mathrm{Z})$.

The structural NATREX model can provide estimates of the effects of the exogenous factors - such as productivity growth or fiscal variables - upon both the medium and long term NATREX exchange rate, and can give forecasts of the adjustment path of the medium-run NATREX R to the long-run level $\mathrm{R}^{*}$. Table 3 summarizes Karadi's results, which are precisely what are implied by the NATREX model summarized in BOX 1 and figures 3-4 above ${ }^{31}$.

\footnotetext{
${ }^{31}$ The theoretical details and derivations are in chapter 4.
} 
Table 3

Hungary: The effects of the fundamental determinants of the real exchange rate in the medium-run and in the long-run.

Exogenous disturbance Medium-run NATREX Long-run NATREX

\begin{tabular}{|l|l|l|}
\hline$\Delta($ Exogenous disturbance $)$ & $(1)$ & $\begin{array}{l}(2) \\
\Delta(\mathrm{R})\end{array}$ \\
\hline $\begin{array}{l}1 \text { percentage point rise in } \\
\text { fiscal consumption/GDP } \\
\text { ratio, i.e., reduction in } \\
\text { saving ratio }\end{array}$ & $3.95 \%$ appreciation & $1.8 \%$ depreciation \\
\hline $\begin{array}{l}1 \text { percentage point } \\
\text { permanent rise in fiscal } \\
\text { productive investment/GDP } \\
\text { ratio }\end{array}$ & $3.95 \%$ appreciation & $1.1 \%$ depreciation \\
\hline $\begin{array}{l}\text { Permanent rise in TFP } \\
\text { growth causing a 1 } \\
\text { percentage point higher } \\
\text { investment/GDP ratio }\end{array}$ & $4.04 \%$ appreciation & $1.55 \%$ appreciation \\
\hline $\begin{array}{l}1 \text { percentage point } \\
\text { reduction in real rate of } \\
\text { interest }\end{array}$ & $0.01 \%$ appreciation \\
\hline $\begin{array}{l}\text { Permanent increase in } \\
\text { perternal demand causing a } 1\end{array}$ & $6.65 \%$ appreciation \\
trade balance/GDP & - & \\
\hline Source: Karadi, Table & & \\
\hline
\end{tabular}

Source: Karadi, Table 4. 
One of the most interesting implications of the NATREX model is that a rise in investment less saving $\Delta(\mathrm{I}-\mathrm{S})$ per se appreciates the real exchange rate in the medium-run but depreciates it in the longer run. This can occur either because time preference, consumption/GDP, rises or that investment/GDP rises - with no change in the trade balance function $\mathrm{B}\left(\mathrm{R} ; \mathrm{Z}_{\mathrm{B}}\right)$. The trajectory of this effect is graphed in figure 3 .

Table 3 rows 1 and 2 concern this effect. For example, the medium-run effect of a rise in fiscal consumption/GDP - a decline in saving - shifts the SI curve to SI(1) and appreciates the real exchange rate from $R(0)$ to $R(1)$ in figure 2. The structural equation estimate of the medium-run effect is seen in the first row/ column (1) in table 3. When the fiscal consumption ratio rises by $1 \%$, the estimated appreciation is $3.95 \%$ in the mediumrun.

As seen in figure 3, in the long-run the NATREX real exchange rate depreciates below its initial level. Table 4/row1/column 2 estimates that when the fiscal consumption ratio rises by $1 \%$, the longer run real exchange rate depreciates by $1.8 \%$.

Row 2 in table 3 concerns the rise in investment $\Delta \mathrm{I}$. The same analysis applies. There is medium-run appreciation and long-run depreciation.

Row 3/table 3 concerns a rise in the growth rate. This corresponds to of NATREX model summarized in BOX 1/last row. Insofar as the rise in total factor productivity raises investment, there will be medium-run appreciation. There is a current account deficit and the debt rises, which is a depressive force in the long-run. However, as the growth rate rises, the debt/GDP ratio declines and the exchange rate appreciates. The result summarized in BOX 1 last column can be understood by the long-run equilibrium condition for a constant debt ratio discussed in chapter 4 , where $B\left(R^{*} ; Z_{B}\right)=(r-g) F^{*}$. The trade balance $\mathrm{B}^{*}$ must be sufficiently great to pay the interest on the debt adjusted for the growth rate $(\mathrm{r}-\mathrm{g}) \mathrm{F}^{*}$. The rise in the growth rate lowers the right hand side for $\mathrm{F}>$ 0 . Therefore, the real exchange rate must appreciate to reduce the trade balance to equal the smaller right hand side.

$A$ rise in foreign demand is included in parameter $Z_{B}$ in the trade balance equation. Figure 4, BOX 1/row 2 shows that a rise in $\mathrm{Z}_{\mathrm{B}}$, that may result from either a rise in productivity - the decline in marginal cost SMC - or a rise in external demand - a rise in $\mathrm{D}$ - which raises the trade balance function, appreciates the real exchange rate and 
reduces the debt/raises net foreign assets. It is the decline in the debt ratio that leads to more appreciation in the long-run than in the medium-run. See NATREX figure 5. Table 3/row 5 shows that this appreciation effect does indeed occur.

No single test per se is conclusive, because the sample period is relatively short. It is best that alternative tests be performed to determine if the results are robust. One can also estimate the reduced forms. ${ }^{32}$. The fundamental determinants of the long-run NATREX are: relative time preference and relative labor productivity for the entire economy. Using the data underlying Christoph Fischer's panel data analysis in table 2, we seek to find a cointegrating equation (12) linking the three variables.

The real exchange rate $\mathrm{R}$ is the real effective exchange rate against a weighted average of Hungary's OECD trading partners. The relative time preference $\delta / \delta *$ is the social consumption/GDP ratio in Hungary relative to the same weighted average of trading partners. Relative total labor productivity $y / y^{*}$ is also measured relative to the same weighted average of trading partners. The sample period is $1996 \mathrm{q} 4$ - 2000q4. (12) $\mathrm{R}^{*}=\mathrm{R}\left(\delta / \delta^{*}, \mathrm{y} / \mathrm{y}^{*}\right) \quad \mathrm{R}_{\delta}<0, \mathrm{R}_{\mathrm{y}}>0$

A unique cointegrating equation was obtained. The signs were precisely those hypothesized and graphed in figures 3 and 5 above or BOX 1/long-run real exchange rate. A rise in social consumption depreciates the long-run real exchange rate and a rise in relative productivity appreciates the long-run real exchange rate. The coefficients are statistically significant. The quantitative estimates differ according to the lag structure. Thus the reduced form estimates are qualitatively the same as those obtained from the structural equations estimation.

\section{Summary:}

- $\quad$ There are clear trends in the real effective exchange rate $\mathrm{R}=\mathrm{REW}-\mathrm{HUN}$.

- The crucial determinant of the long-run real exchange rate is relative total labor productivity $\mathrm{y} / \mathrm{y}^{*}=\mathrm{UTOT}-\mathrm{HUN}$. The trend in the long-run equilibrium real exchange rate follows the trend in relative productivity.

Figure 7 graphs $^{33}$ in normalized form the real effective exchange rate, relative productivity and the smoothed relative labor productivity UTOTHUNHP, using the H-P

\footnotetext{
${ }^{32}$ See the discussion of this procedure and its application to the euro in chapter 7.

33 Since the results are based upon Fischer's data, I use his acronyms in graph 7.
} 
filter. These results are consistent with those that were found both in table 3 based upon estimates of the structural equations and from cointegrating equation (12).

The trend of the real exchange rate will deviate away from that in relative productivity insofar as relative time preference is changing. Neither PPP nor the B/S hypothesis equation (1) is useful in explaining trends in the real exchange rate and the balance of payments.

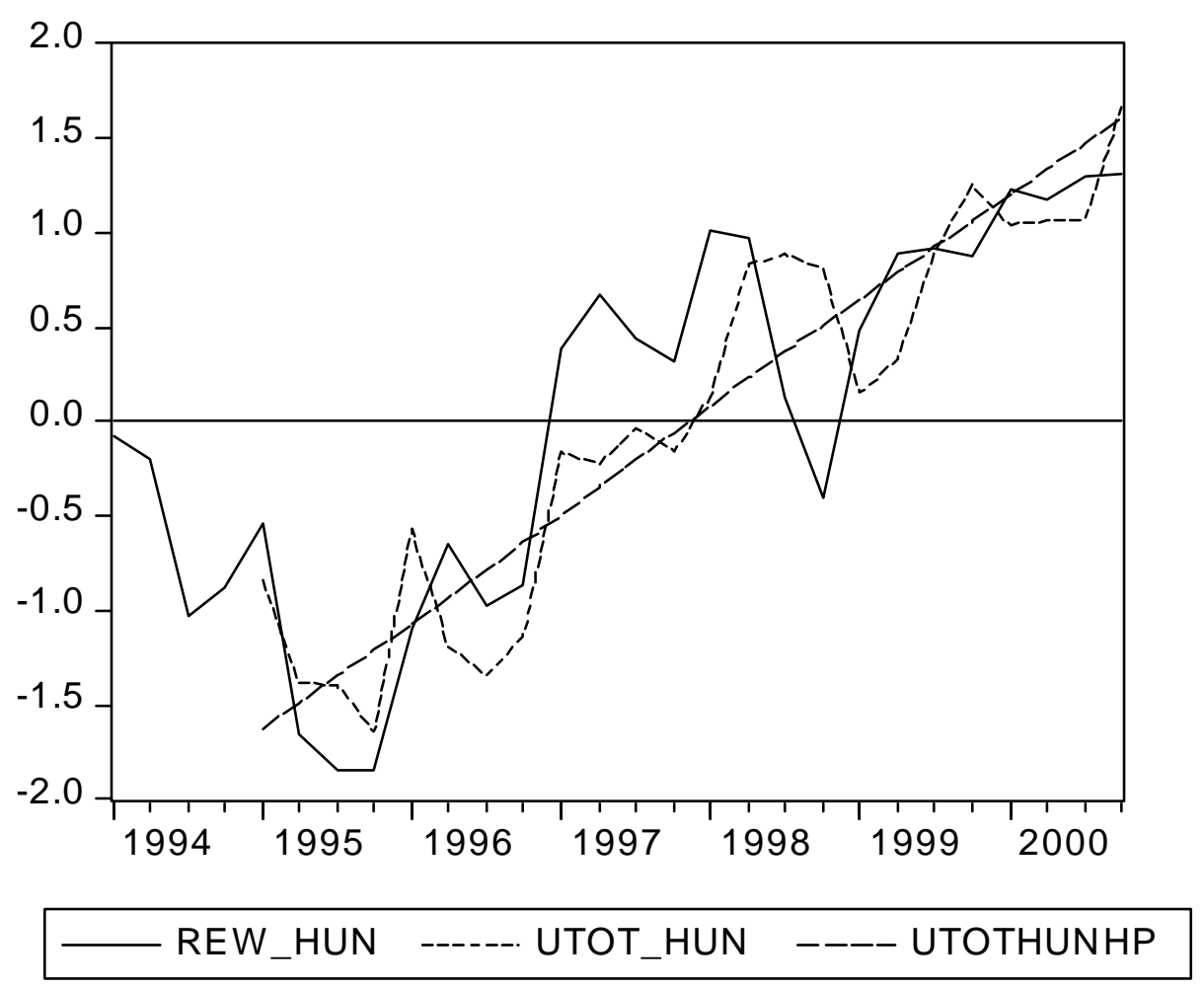

Figure 7. Real effective exchange rate Hungary REX_HUN, Relative labor productivity UTOT_HUN, smoothed relative labor productivity using H-P filter UTOTHUNHP. Variables are normalized. Data supplied by C. Fischer/Bundesbank. 


\subsection{Czech Republic}

The Czech Koruna appreciated in real terms, since the beginning of transformation in 1993, as seen in figure 1 above. Real appreciation occurred primarily through the rise in relative prices, since there was no trend in the nominal exchange rate.

The questions examined by Jan Frait and Lubos Komarek (F-K) were: why did the Czech Koruna real exchange rate appreciate? Is the real appreciation sustainable and consistent with "equilibrium"? How should one model the equilibrium trajectory of the real exchange rate? Will the appreciation lead to a lower external competitiveness and higher external deficit and debt? Is the real appreciation compatible with low inflation? They stated that the objective of economic theory is to explain what factors and processes influence the development of the real exchange rate in transition economies such as the CEEC.

Clearly, the PPP hypothesis is not consistent with the trend appreciation. Frait and Komarek also show that the B/S hypothesis is overly simplistic. For the Czech Republic approximately $80 \%$ of the percentage appreciation of the CPI weighted real exchange rate came from the appreciation of the PPI weighted real exchange rate. See table 1 above.

In the period examined 1993q1 - 2000q4, there were structural changes and capital mobility. The variable to be explained is the real exchange rate $\mathrm{R}(\mathrm{CPI})$ relative to Germany. They used the NATREX model of a "sustainable" or "equilibrium" real exchange rate as their benchmark, They examined to what extent the trend of actual real exchange rate can be explained in terms of the trajectory of the real exchange rate implied by the NATREX dynamic stock-flow growth model. Thereby, a measure of misalignment is obtained and the prediction is that the real exchange rate will converge to the NATREX. The emphasis was upon explanation/ theory, which would be useful for policy, and not upon data mining to account for variations in the real exchange rate. First, their econometric tests and results are summarized. Second, their economic significance and implications are discussed.

As summarized in BOX 1 and in the previous section, the vector $\mathrm{Z}$ of the fundamental determinants of the real exchange rate are the variables that shift the SI and CA curves in figure 2. F-K used as vector Z: saving rate/time preference/consumption ratio, productivity $\mathbf{y}$, terms of trade $\mathbf{T}$, foreign direct investment FDI, and world real 
interest rate $\mathbf{r}$. A decline in the saving rate/rise in social consumption ratio produces the trajectories in figure 3. A rise in productivity generates the trajectories in figure 5. A rise in foreign direct investment FDI first leads to the trajectory in figure 3. As productivity and growth rise as a result of cumulative investment ${ }^{34}$, the trajectory in figure 5 is generated. An improvement in exogenous terms of trade also leads to trajectories in figure 5 .

The saving ratio variable was problematic, since it displayed large jumps that are difficult to interpret from an economic point of view. Since it lacked explanatory power F-K did not include it in vector $\mathrm{Z}$ of fundamental determinants.

The goal of econometric analysis is to estimate the trajectories, involving changes in the stocks of assets and the growth rate ${ }^{35}$, to the long-run equilibrium. These adjustments take time. Estimates of long-run equilibrium based upon quarterly data are problematic, due to short period. The cointegration/vector error VEC correction approach conforms to the dynamic model described in chapter 4 and for the Euro in chapter 7. The VEC equation estimated is:

(13) $\Delta \mathrm{R}_{\mathrm{t}}=\mathrm{a}(\mathrm{R}-\mathrm{R}(\mathrm{Z}))_{\mathrm{t}-1}+\mathrm{B} \cdot \Delta \mathrm{Z}, \quad \mathrm{a}<0$, $\mathrm{Z}=$ [y = productivity, FDI, TOT = terms of trade, $\mathrm{r}=$ world real interest rate $]$

Cointegration equation (14) is the long-run equilibrium, which is summarized in column 1 in table 4.

(14) $\mathrm{R}^{*}=\mathrm{R}(\mathrm{Z})=\mathrm{R}\left(\mathrm{y}^{+}, \mathrm{T}^{+}, \mathrm{FDI}^{+}, \mathrm{r}^{-}\right)$

The Error correction component is in column 2 of table 4, which represents the shifts in the SI and CA curves in figure 2.

The results in table 4 are consistent with those implied by the NATREX model in $B O X 1$. The aim is not to establish exactly by how much the Czech Koruna may have been misaligned, but to determine if the current exchange rate trend is consistent with the trend in the equilibrium real exchange rate. Moreover, it is important to understand and to

\footnotetext{
${ }^{34}$ One could equivalently state that capital is gradually raised as a result of the path of investment. In turn the higher capital raises productivity, which shifts the CA function.

${ }^{35}$ In the earlier NATREX work capital is a variable. The usual measure of capital is the sum of investment. Since capital is not objectively measurable, we have been using (see chapter 4 appendix B) an alternative but mathematically equivalent concept. This substitutes an equation for the rate of growth of GDP for the growth of capital.
} 
predict how policy changes will affect the trend of the real exchange rate.

\section{Table 4}

Czech Republic: Empirical results, equation (13), 1993q1 - 2004q4

$\begin{array}{llll}\text { Real exchange rate } & (1) \underline{\text { Cointegrating equation }} & & (2) \underline{\text { Error correction }(\Delta \mathrm{R})} \\ \text { Productivity } & \text { appreciate } & \Delta \text { (Productivity) } & \text { appreciate } \\ \text { FDI } & \text { appreciate } & \Delta(\mathrm{FDI}) & \text { appreciate } \\ \text { Terms of trade } & \text { appreciate } & \Delta \text { (Terms of trade) } & \text { appreciate } \\ \text { World real interest rate } & \text { depreciate } & \Delta \text { (real interest rate) } & \text { depreciate }\end{array}$

Coefficients are significant and have the hypothesized sign.

Source: Frait and Komarek, Appendix.

The logic of the NATREX is that distinctions are made between: (a) endogenous and exogenous variables ${ }^{36}$, and (b) the medium and longer-run equilibrium. Insofar as (a) is concerned, there may very well be inter-relations among the regressors in the econometric equations. Jan Frait posed ${ }^{37}$ some pertinent questions about point (a) above. Are the terms of trade exogenous? What is the relation between the terms of trade TOT and FDI? His argument is that the Czech economy experienced sustained improvements in the TOT since the transition from Socialism. The sustained decline in the TOT was probably the best evidence of devastation of the economy during the Socialist times. The improvements in the TOT reflect structural changes in the economy, where there is greater efficiency and productivity due to FDI inflows. Thus it is a question to what extent the TOT and FDI are both independent variables in the regressions.

Frait's argument is consistent with the NATREX interpretation of the theme of Lommatzsch and Tober discussed in section (3.1) above. Productivity $\mathrm{y}_{\mathrm{t}}$ (3) $y_{t}=y(0) \exp \left[f b_{s} I_{s} d s+z t\right]$ is the exponential of the integral of the investment ratio times the productivity of investment, plus the improved resource allocations over the period $(0, \mathrm{t})$. FDI is induced by the potential return on optimal investment and leads to rises in $b_{s} I_{s}$ as well as in $z$. This

\footnotetext{
36 The eclectic-econometric equations are not concerned with point (a) and just search for cointegrating equations.

${ }^{37}$ This was done in correspondence with the author.
} 
is manifested as shifts from low value added to high value added goods, which made possible by the higher productivity. These goods can now compete in the world market. In figure 4, output has both a quality and a quantity dimension. Theoretically, the CA curve in figure 2 shifts to the right. The story is described in BOX 1 in the row labeled $\Delta \mathrm{Z}_{\mathrm{B}}$. This shift is detected empirically as an improvement in TOT = prices exports/prices of imports. Therefore FDI, productivity, changes in structure of the economy and the TOT are interrelated in the manner summarized in equation (3).

Due to the short sample period, cointegration analysis, which attempts to estimate both medium-run and longer run equilibria, does not have much power. It is more convincing if a series of methods and studies arrive at similar qualitative results ${ }^{38}$. My aim is to interpret them in the NATREX framework.

A relatively robust NATREX explanation of the evolution of the Czech real exchange rate, which is not amenable to the limitations discussed above, can be presented in the following way. I use Fischer's data ${ }^{39}$ and acronyms for the Czech Republic (CZE) the way we used it for Hungary. The real effective exchange rate R = REW-CZE is measured relative to a weighted average of the OECD trading partners. Total labor productivity $\mathrm{y} / \mathrm{y}^{*}=\mathrm{UTOT}-\mathrm{CZE}$ is measured relative to the same weighted average. Relative social consumption/GDP is also measured the same way $\delta / \delta^{*}=\mathrm{c} / \mathrm{c}^{*}=\mathrm{KQ}-\mathrm{CZE}$. Figure 8 graphs the actual real exchange rate $\mathrm{R}$ and smoothed values, using the H-P filter, of relative productivity UTOTCZHP and of relative time preference KQCZHP. Any sensible smoothing method for $\mathrm{c} / \mathrm{c}^{*}$ and $\mathrm{y} / \mathrm{y}^{*}$, such as moving averages, will serve just as well.

\footnotetext{
38 One study by Egert and Lommatzsch (E/L) did cointegration analyses using either the CPI or the PPI weighted real exchange rate and employed several different methods of estimation. They obtained a cointegrating equation in the case of each real exchange rate, and method of estimation, for the Czech currency. Their results (E/L:table 1a), summarized in (a) - (c), are consistent with those of Frait and Komarek and the NATREX model. (a) Labor productivity in either industry or in the overall economy is found to be the most stable determinant of either R(CPI) or R(PPI). Again the B/S hypothesis is rejected. (b) The similar results for R(CPI) and R(PPI) are consistent with the theoretical framework where appreciation comes from the shifts in the CA curve in figure 2, and the dynamics are as described in figure 4. (c) Foreign debt depreciates the real exchange rate. This is consistent with the dynamics that the growth in the foreign debt shifts the CA curve to the left along the SI curve and depreciates the real exchange rate. In a stable system, the growth in the debt must lead to a rightward shift in the SI curve, which increases the depreciation.

${ }^{39}$ These are the data in Fischer's panel analysis, summarized in table 2 above.
} 
Figure 8 shows that there is a non-monotonic trend in the real exchange rate. Two fundamental factors explain the longer-run movements. First, there is a trend in relative time preference KQ. In the NATREX model, this trend leads to long-run depreciation. See BOX 1, row 1. Figure 3 describes this populist scenario: a rise in social consumption/decline in social saving. Second: There are two trends in relative productivity UTOT. For the first three or so years, relative productivity is rising. This is the force for long-run appreciation. By 1997, the trend is reversed. Productivity is growing at a slower rate than the OECD trading partners. This is no longer a force for longer run appreciation. Third is the net effect of the two different trends. The earlier growth in productivity offset the effects of populist policies, and the real exchange rate appreciated rapidly. In the second part of the period, the decline in the trend rate of appreciation was due to the fact that the lower growth in relative productivity was not able to offset to the same extent the effects of populist policies discussed in chapter one.

Figure 8. Czech Republic. Real effective exchange rate REW-CZE, smoothed relative time preference KQCZHP, smoothed relative productivity UTOTCZHP. 

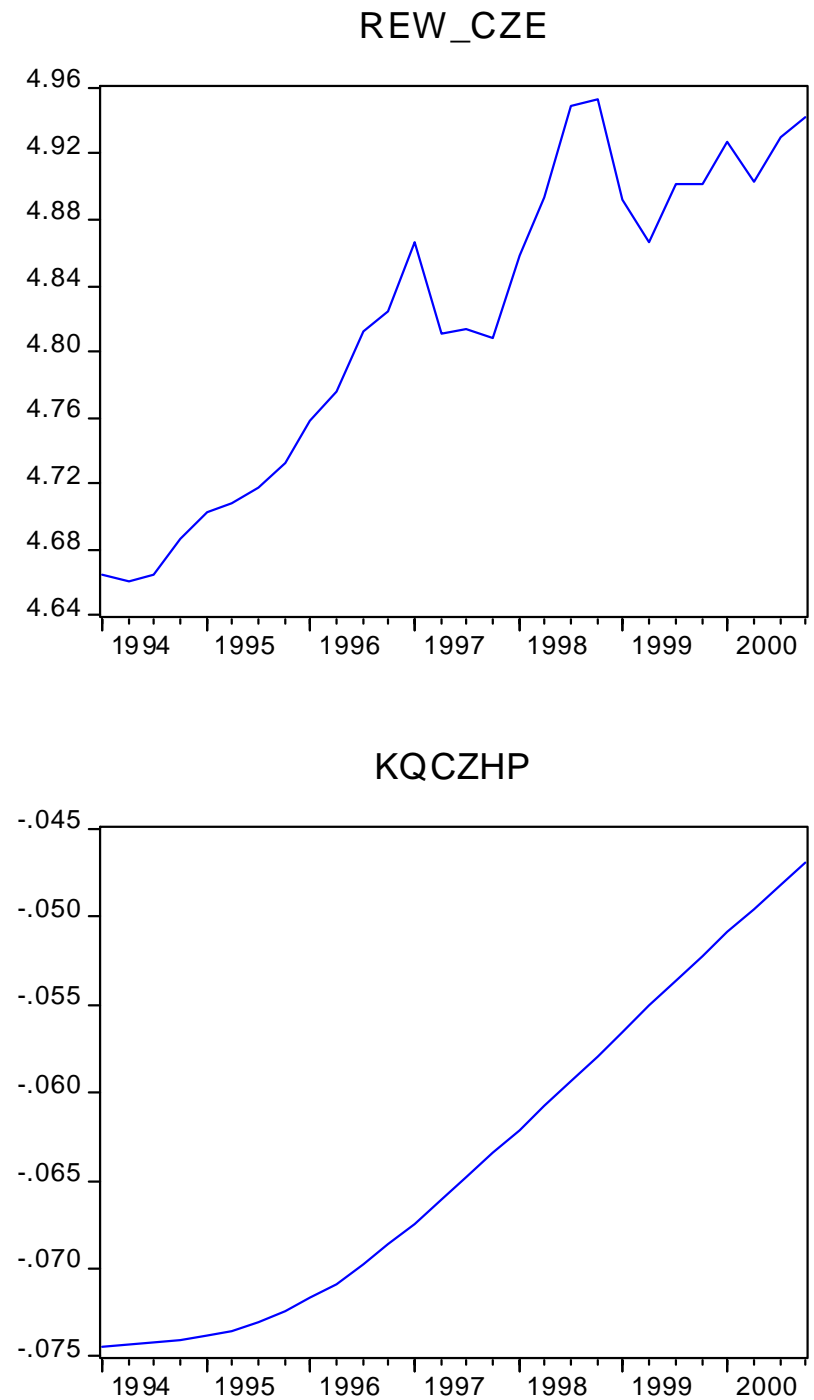

UTOTCZHP

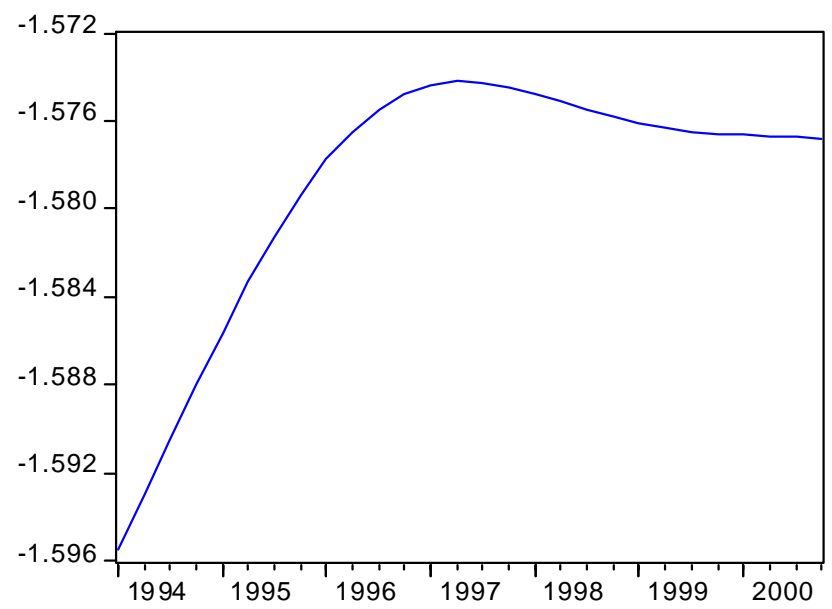




\section{A Summing Up: Policy Implications}

Vaclav Klaus, President of the Czech Republic, delivered a significant address (June, 2004) concerning policy issues in the transition economies. He opened his remarks in the following way.

"In recent weeks we could hear and read hundreds of comments on the historical significance of the enlargement of the European Union by ten new, mostly former communist countries of Central and Eastern Europe. We could hear many words, but I fear hardly any serious, well founded analyses. It was the a priori position of almost all speakers that it was a clearly positive and productive change for all concerned. Any indication to think about this statement, any indication of criticism, question mark or comments regarding the costs involved in enlargement were considered short-sighted or ill-intentioned....I can neither present an in-depth scientific analysis of the effects of this year's EU enlargement nor an empirical analysis. This remains a long-term task for other people, even though it will not be an easy task for them either for lack of a simple scientific methodology and tested instruments."

The NATREX analysis in this chapter responds to Klaus's cogent remarks. At what pace should the countries enter the Euro area and at what exchange rate? First, the NATREX explains what are the fundamental determinants of equilibrium/sustainable real exchange rates, and the transmission mechanism between policies and sustainable real exchange rates. A real exchange rate significantly higher - more appreciated relative to the NATREX - is unsustainable and will lead to serious problems. The dangers of selecting unsustainable exchange rates and policies may be what Vaclav Klaus had in mind when he wrote the following.

"The new member states... accepted the European (and originally German) model... of a social market economy that is unambiguously connected with the low competitiveness of the firms, with the rigidity of the entire economy, with high unemployment and low economic growth. This will not lead these countries, whose level of development is lower than the European average, to real economic convergence. There is even the risk that, quite to the contrary, nominal convergence... will be the brake on real convergence. It should not be necessary to stress this in a country [Germany] that experienced 
unification, in which the effects of unification (or rapid nominal convergence) are well known."

Second: The NATREX analysis is relevant regardless of whether the nominal rate is fixed, there is a currency board or there is a more flexible exchange rate regime. If the nominal exchange rate is relatively fixed, then the variation in the real exchange rate will occur through differential rates of inflation.

We already have shown in detail how NATREX analysis explains the trends of the real exchange rate for Hungary and for the Czech Republic. A desirable characteristic of the analysis is that it can be applied to countries in various stages of structural change. The case of Bulgaria is relevant for our argument. We draw upon the work on Chobanov and Sorsa (C-S) to further demonstrate these points.

Bulgaria had high rates of inflation, 321\% in 1996 and 548\% in 1997, followed by a deep financial crisis. A Currency Board Authority CBA was introduced in July 1997 to ensure financial stability, and Bulgaria also liberalized most capital movements. At first, the currency was fixed to the German Mark and then to the Euro. Since the introduction of the CBA, the real value of the currency appreciated by $30 \%$ and the current account deficit widened to $8.5 \%$ of GDP. The important questions studied by $\mathbf{C}$-S are whether the real appreciation indicates a misalignment, and whether the current account deficit is a cause for concern.

Chobanov and Sorsa used the NATREX methodology to evaluate if the currency was significantly misaligned. Their econometric results are that the real appreciation of the exchange rate reflects changes in fundamentals, such as productivity, terms of trade, gross saving, world interest rates and foreign direct investment. The appreciation of the real exchange rate since stabilization reflects the appreciating NATREX and they did not find misalignment in the post July 1997 period.

The Bulgarian situation can be demonstrated by using figure 9 which relates ${ }^{40}$ the logarithm of the equilibrium nominal exchange rate $\log \mathrm{N}^{\mathrm{e}}$ to the logarithm of relative prices $\log \left(\mathrm{p} / \mathrm{p}^{*}\right)$. It is the graph of the equation

(15) $\log \mathrm{N}_{\mathrm{t}}^{\mathrm{e}}=\log \mathrm{R}\left(\mathrm{Z}_{\mathrm{t}}\right)-\log \left(\mathrm{p} / \mathrm{p}^{*}\right)_{\mathrm{t}}$

\footnotetext{
${ }^{40}$ This is the same as figure 1-4 in chapter 1.
} 
The NATREX is $\log R\left(Z_{t}\right)$, which is the vertical intercept, and the slope of the line is minus one. The PPP hypothesis is that the equilibrium nominal rate lies along a given line: the equilibrium real exchange rate is constant. We have shown that this is not a correct description of the transition economies, and that the equilibrium real exchange rate $R\left(Z_{t}\right)$ varies with relative productivity and time preference. Two values for the NATREX are drawn in figure 9, where $R(1)>R(0)$.

$\log \mathrm{Ne}$

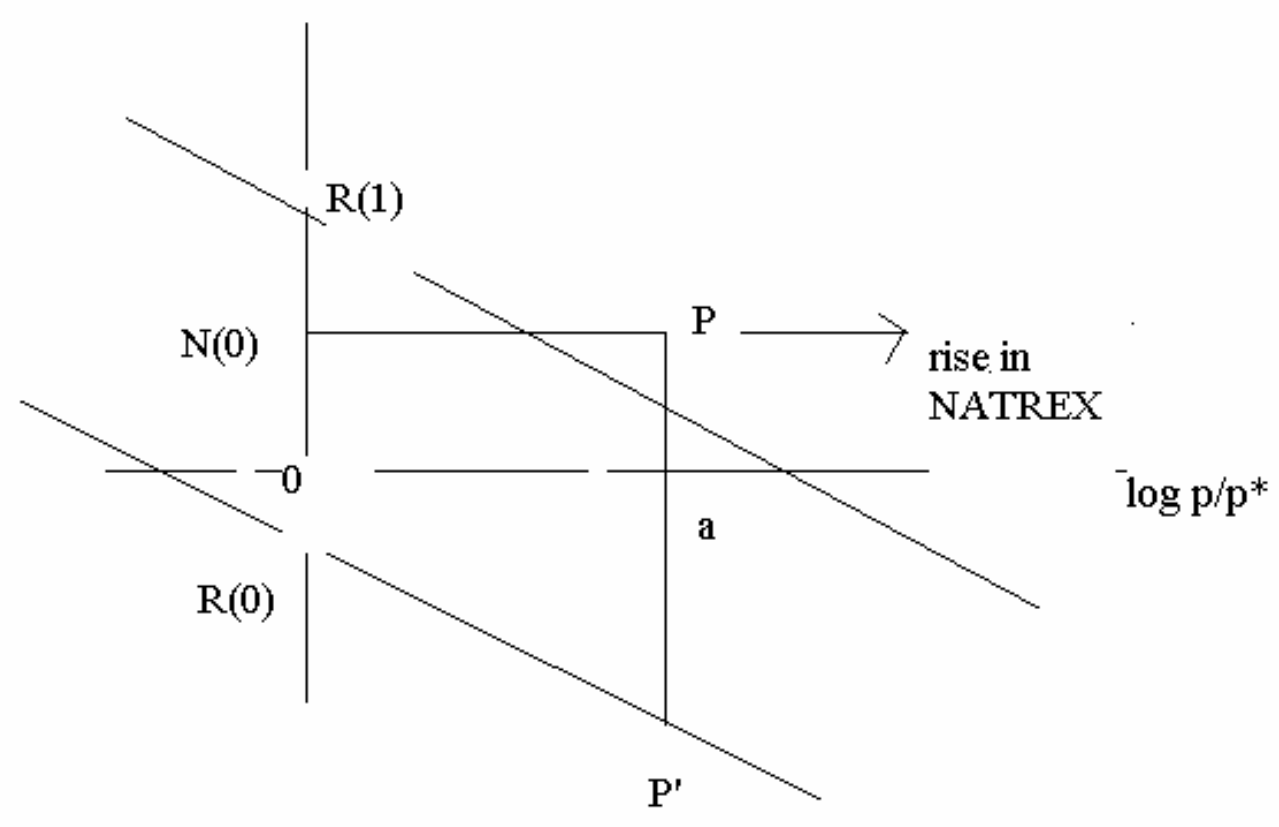

Figure 9. Nominal exchange rate N, the NATREX is R and relative prices (p/p*).

Prior to 1997, the NATREX was R(0), and the nominal exchange rate was N(0). Inflation raised relative prices to $a$. The economy is at point $\mathrm{P}$. The nominal exchange rate was overvalued by distance $\mathrm{P}-\mathrm{P}^{\prime}$. The misalignment produced the financial disasters that (C-S) described.

If the nominal exchange rate were fixed at $\log \mathrm{N}=0$, relative prices remained at $a$ and the NATREX remained at R(0), the CBA would not have been sustainable ${ }^{41}$. After stabilization, the consequent growth of relative productivity raised the NATREX from

\footnotetext{
${ }^{41}$ As we know from the case of Argentina, a currency board is not necessarily viable if there is a serious misalignment where the real exchange rate rises significantly above the NATREX. This was the argument made in chapter six to explain the currency crises in South-East Asia.
} 
$\mathrm{R}(0)$ in the direction of $\mathrm{R}(1)$. The lines were shifting up-to the right. This means that the higher relative price ratio $a$ is more likely to be sustainable at the nominal exchange rate of $\log \mathrm{N}=0$.

Figure 10, based upon Fischer's data shows in a direct manner what happened. The real effective exchange rate is REW_BLG and the relative productivity ${ }^{42}$ smoothed using the HP filter ${ }^{43}$ is denoted UTOTBLGHP. The variables are normalized, so that orders of magnitude are seen graphically.

From 1993-97, the real exchange rate was rising/appreciating, while smoothed relative productivity was falling - figure 10 . Thus the real exchange rate was appreciating/rising while the NATREX was falling. The misalignment was P-P' in figure 9. Stabilization occurred in July 1997. From then on, the trend in productivity was positive and rising. This means that the NATREX was rising in the direction of $R(2)$ in figure 9. The trend in the real exchange rate was following the smooth trend in the NATREX. That is why (C-S) argue that the stabilization was effective and that the CBA is viable.

\footnotetext{
${ }^{42}$ Fischer measures the variables relative to a weighted average of the trading partners.
}

${ }^{43}$ Smoothing by moving averages is equally good. 


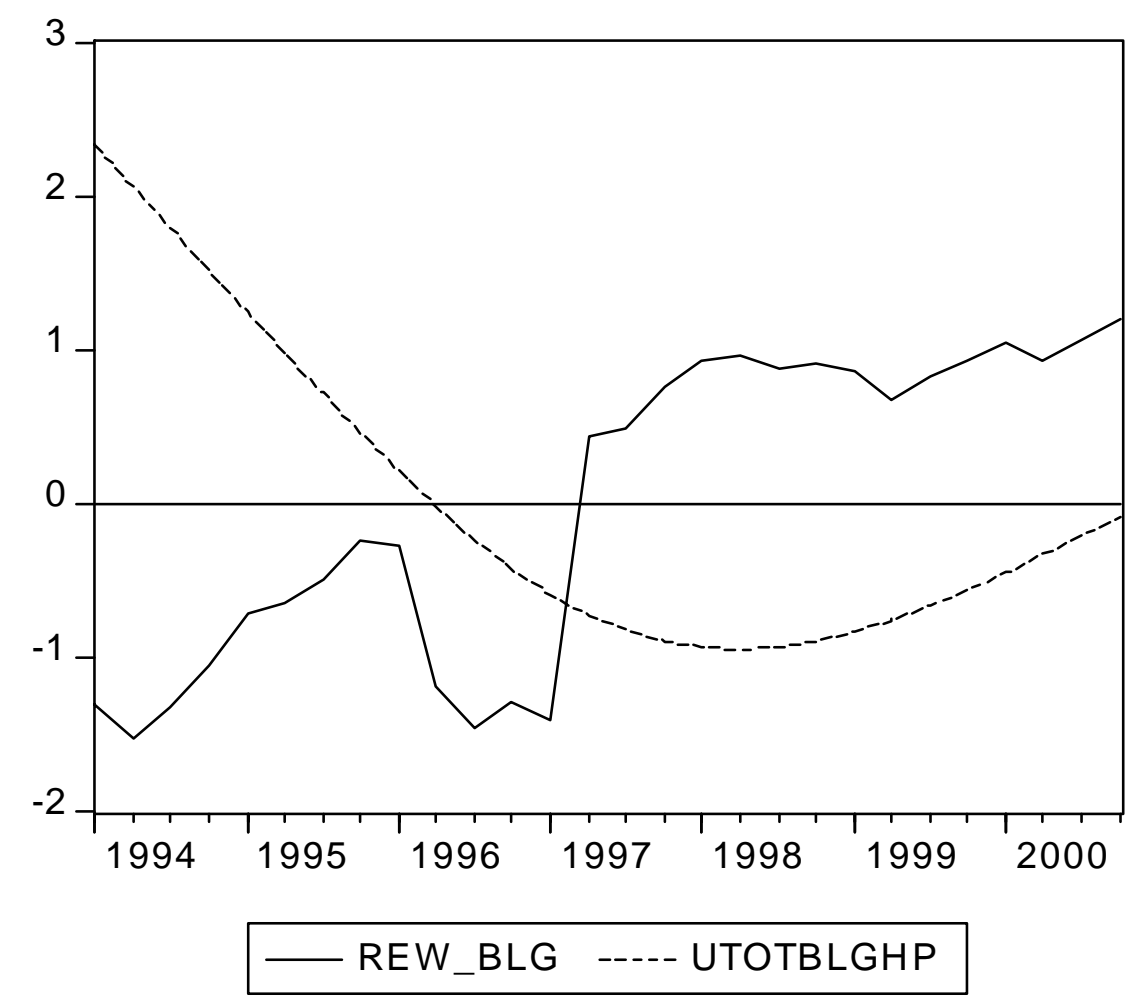

Figure 10. Bulgaria. The real effective exchange rate REW-BLG, relative productivity, smoothed UTOTBLGHP, normalized variables.

Poland provides a contrast to Bulgaria. Figure 11, again based upon Fischer's data, plots the real effective exchange rate of Poland REW_POL, the relative productivity UTOT_POL and the smoothed value of the latter, using the H-P filter UTOTPOLHP. Unlike Bulgaria, the trend in productivity generated the trend in the real effective exchange rate. The Polish curves in figure 9 were shifting to the right. The real exchange rate appreciated primarily via relative inflation. However, serious misalignment is not apparent. 


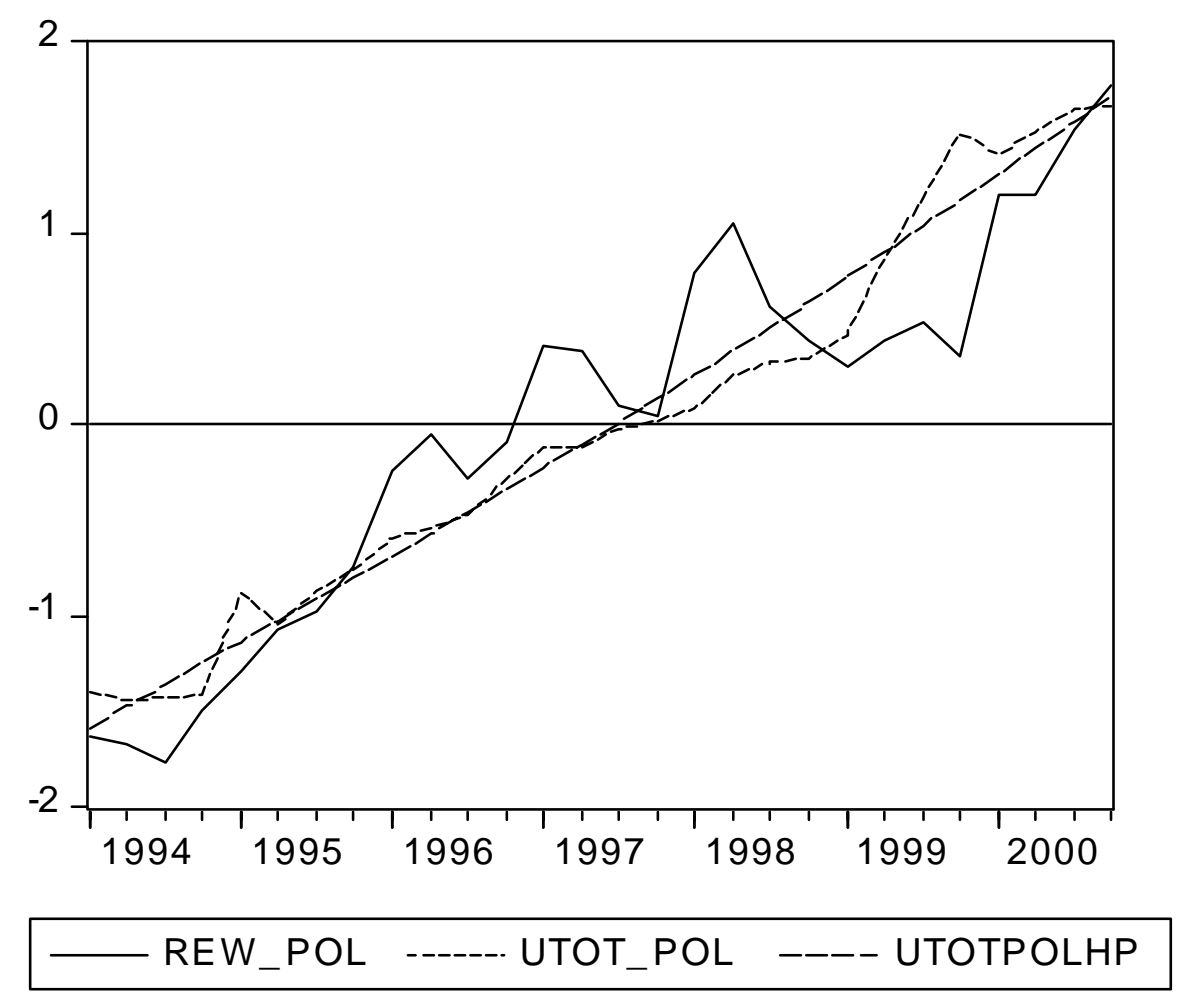

Figure 11. Poland. Real effective exchange rate REW-POL, relative productivity UTOTPOL, smoothed relative productivity UTOTPOLHP.

At what pace should the country enter ERM-II and the Euro area? The answer depends upon the trend of the NATREX. If the dominant trend is a continued rise in relative productivity, the NATREX will rise above line $\mathrm{R}(1)$ in figure 9. With the ERMII, which establishes a central parity for the nominal exchange rate, the relative prices must rise in the direction of the vector in figure 9. The nominal exchange rate $\log \mathrm{N}=0$ would be undervalued at relative prices $a$. This means that there will be a steady rise in central bank reserves and there will be inflationary pressures. The rate of inflation will be greater than in the rest of the EMU, leading the economy to points greater than $a$.

A lesson from NATREX is that: insofar as relative productivity is rising and the nominal exchange rate is fixed, relative inflation must rise. It would be a mistake, and futile, to implement measures that will inhibit investment and growth. 
To mitigate the inflation, the country should postpone entering the euro area until its productivity is growing at the same rate as in the euro area, when the ratio $y / y *$ has stabilized. If productivity is growing at the same rate $y / y^{*}$ is constant, then marginal costs can be equated with a discrete, once and for all, change in relative input prices. If however there is a trend in relative productivity, then there must be a trend in relative nominal input prices.This means differential rates of inflation.

Another scenario is that a country that enters the Euro area at nominal exchange rate at $\log \mathrm{N}=0$ then engages in populist policies that raise time preference - increases in the high employment budget deficit - and lower the growth of productivity. If the rise in time preference effect is stronger than the productivity effect, the NATREX declines - the line in figure 9 shifts down. At the origin where $\left(\log N=0, \log \mathrm{p} / \mathrm{p}^{*}=0\right)$, the nominal exchange rate is overvalued. The economy will be less competitive, exports will be adversely affected, there will be a loss of reserves, and employment and growth will decline. Since the nominal exchange rate is fixed at $\log N=0$, there is no alternative but to lower wages and prices. Given a low level of wage-price flexibility, the economy will stagnate.

Initially upon entry into the ERM-II, the central parity will seem to be sustainable. Insofar as the country announces its parity $\log N=0$, there will be speculative capital flows that will be based upon the anticipation that this nominal rate will be the rate that is ultimately fixed. Consequently the actual nominal rate will lie in a band around this rate, even though the NATREX is very likely to vary due to relative productivity and thrift. Say that there is a downward trend in the NATREX due to trends in productivity and thrift. Then the combination of the established nominal exchange rate $\log \mathrm{N}=0$ and no relative inflation $\log \mathrm{p} / \mathrm{p}^{*}=0$ will not be sustainable. Although "tensions" may not be discernable in the first few years due to speculation, a crisis is inevitable. If the NATREX is depreciating, then there is no alternative but a reduction of wages and prices. Social policies that prevent that from occurring will lead to the East German situation cited by Vaclav Klaus.

The policy conclusionis that insofar as the countries are committed to entry into the Euro area, they should not ignore the likely dangers of misalignment. The Central 
Banks should calculate the trend of the NATREX, as was done in the Czech Republic and Hungary. 


\section{REFERENCES}

Chobanov, Dimitar and Piritta Sorsa (2004), Competitiveness in Bulgaria: An Assessment of the Real Effective Exchange Rate, International Monetary Fund, Working Paper WP/04/37.

Detken, Carsten, A. Dieppe, J. Henry, Carmen Marin and Frank Smets, "Determinants of the Effective Real Exchange Rate of the Synthetic Euro: Alternative Methodological Approaches", (2002) Australian Economic Papers, 41 (4), December

Égert, Balazs, László Halpern and Ronald MacDonald (2004) Equilibrium Exchange Rates in Transition Economies: Taking Stock of the Issues

Égert, Balazs and Kirsten Lommatzsch (2004), Equilibrium Exchange Rates in the Transition countries, William Davidson Institute Univ. Michigan Business School, WP \# 676.

Fischer, Christoph, (2002) Fundamental determinants of real exchange rate movements in the central and eastern European accession countries, Deutsche Bundesbank, Monthly Report, October.

(2002) Real currency appreciation in accession countries: BalassaSamuelson and investment demand, Discussion paper 19/02, Economic Research Centre of Deutsche Bundesbank, July

and Karlhans Sauernheimer (2002) A History of the D-Mark's Real

External Value, Australian Economic Papers, 41 (4).

Frait, Jan and Lubos Komarek (2001), Real Exchange Rate Trends in Transition

Countries, Warwick Economic Research Papers, No. 596, University of Warwick

International Monetary Fund (2004), World Economic Outlook, Washington DC, April.

Karadi, Peter (2003), Structural and Single Equation Estimation of the NATREX

Equilibrium Real Exchange Rate, Central Bank of Hungary, Working Paper.

Klaus, Vaclav (2004) Implications of this year's EU enlargement: A preliminary analysis, CESifo Forum, autumn.

Lommatzsch, Kirsten and Silke Tober (2005) What is behind the real appreciation of the accession countries? An investigation of the PPI-based real exchange rate, Economic Systems

Stein, Jerome L. Stochastic Optimal Control, International Finance and Debt Crises, Oxford University Press, forthcoming. 


\title{
CESifo Working Paper Series
}

\author{
(for full list see www.cesifo.de)
}

1382 Christian Gollier, Optimal Illusions and Decisions under Risk, January 2005

1383 Daniel Mejía and Marc St-Pierre, Unequal Opportunities and Human Capital Formation, January 2005

1384 Luis H. R. Alvarez and Erkki Koskela, Optimal Harvesting under Resource Stock and Price Uncertainty, January 2005

1385 Ruslan Lukach, Peter M. Kort and Joseph Plasmans, Optimal R\&D Investment Strategies with Quantity Competition under the Threat of Superior Entry, January 2005

1386 Alfred Greiner, Uwe Koeller and Willi Semmler, Testing Sustainability of German Fiscal Policy. Evidence for the Period 1960 - 2003, January 2005

1387 Gebhard Kirchgässner and Tobias Schulz, Expected Closeness or Mobilisation: Why Do Voters Go to the Polls? Empirical Results for Switzerland, 1981 - 1999, January 2005

1388 Emanuele Bacchiocchi and Alessandro Missale, Managing Debt Stability, January 2005

1389 Assar Lindbeck and Dirk Niepelt, Improving the SGP: Taxes and Delegation rather than Fines, January 2005

1390 James J. Heckman and Dimitriy V. Masterov, Skill Policies for Scotland, January 2005

1391 Emma Galli \& Fabio Padovano, Sustainability and Determinants of Italian Public Deficits before and after Maastricht, January 2005

1392 Angel de la Fuente and Juan Francisco Jimeno, The Private and Fiscal Returns to Schooling and the Effect of Public Policies on Private Incentives to Invest in Education: A General Framework and Some Results for the EU, January 2005

1393 Juan C. Conesa and Carlos Garriga, Optimal Response to a Demographic Shock, January 2005

1394 Christian Gollier, Optimal Portfolio Management for Individual Pension Plans, February 2005

1395 Ruslan Lukach, Joseph Plasmans and Peter M. Kort, Innovation Strategies in a Competitive Dynamic Setting, February 2005

1396 Gebhard Kirchgässner, (Why) Are Economists Different?, February 2005

1397 Marko Köthenbürger, Panu Poutvaara and Paola Profeta, Why are More Redistributive Social Security Systems Smaller? A Median Voter Approach, February 2005 
1398 Gabrielle Demange, Free Choice of Unfunded Systems: A First Assessment, February 2005

1399 Carlos Fonseca Marinheiro, Sustainability of Portuguese Fiscal Policy in Historical Perspective, February 2005

1400 Roel M. W. J. Beetsma and Koen Vermeylen, The Effect of Monetary Unification on Public Debt and its Real Return, February 2005

1401 Frank Asche, Petter Osmundsen and Maria Sandsmark, Is It All Oil?, February 2005

1402 Giacomo Corneo, Media Capture in a Democracy: The Role of Wealth Concentration, February 2005

1403 A. Lans Bovenberg and Thijs Knaap, Ageing, Funded Pensions and the Dutch Economy, February 2005

1404 Thiess Büttner, The Incentive Effect of Fiscal Equalization Transfers on Tax Policy, February 2005

1405 Luisa Fuster, Ayşe İmrohoroğlu and Selahattin İmrohoroğlu, Personal Security Accounts and Mandatory Annuitization in a Dynastic Framework, February 2005

1406 Peter Claeys, Policy Mix and Debt Sustainability: Evidence from Fiscal Policy Rules, February 2005

1407 James M. Malcomson, Supplier Discretion over Provision: Theory and an Application to Medical Care, February 2005

1408 Thorvaldur Gylfason, Interview with Assar Lindbeck, February 2005

1409 Christian Gollier, Some Aspects of the Economics of Catastrophe Risk Insurance, February 2005

1410 Gebhard Kirchgässner, The Weak Rationality Principle in Economics, February 2005

1411 Carlos José Fonseca Marinheiro, Has the Stability and Growth Pact Stabilised? Evidence from a Panel of 12 European Countries and Some Implications for the Reform of the Pact, February 2005

1412 Petter Osmundsen, Frank Asche, Bård Misund and Klaus Mohn, Valuation of International Oil Companies -The RoACE Era, February 2005

1413 Gil S. Epstein and Shmuel Nitzan, Lobbying and Compromise, February 2005

1414 Marcel F. M. Canoy, Jan C. van Ours and Frederick van der Ploeg, The Economics of Books, February 2005 
1415 Eric A. Hanushek and Ludger Wößmann, Does Educational Tracking Affect Performance and Inequality? Differences-in-Differences Evidence across Countries, February 2005

1416 George Kapetanios and M. Hashem Pesaran, Alternative Approaches to Estimation and Inference in Large Multifactor Panels: Small Sample Results with an Application to Modelling of Asset Returns, February 2005

1417 Samuel Mühlemann, Jürg Schweri, Rainer Winkelmann and Stefan C. Wolter, A Structural Model of Demand for Apprentices. February 2005

1418 Giorgio Brunello and Lorenzo Rocco, Educational Standards in Private and Public Schools, February 2005

1419 Alex Bryson, Lorenzo Cappellari and Claudio Lucifora, Why so Unhappy? The Effects of Unionisation on Job Satisfaction, March 2005

1420 Annalisa Luporini, Relative Performance Evaluation in a Multi-Plant Firm, March 2005

1421 Giorgio Bellettini and Carlotta Berti Ceroni, When the Union Hurts the Workers: A Positive Analysis of Immigration Policy, March 2005

1422 Pieter Gautier, Michael Svarer and Coen Teulings, Marriage and the City, March 2005

1423 Ingrid Ott and Stephen J. Turnovsky, Excludable and Non-Excludable Public Inputs: Consequences for Economic Growth, March 2005

1424 Frederick van der Ploeg, Back to Keynes?, March 2005

1425 Stephane Dees, Filippo di Mauro, M. Hashem Pesaran and L. Vanessa Smith, Exploring the International Linkages of the Euro Area: a Global VAR Analysis, March 2005

1426 Hans Pitlik, Friedrich Schneider and Harald Strotmann, Legislative Malapportionment and the Politicization of Germany's Intergovernmental Transfer System, March 2005

1427 Konstantinos Angelopoulos and Apostolis Philippopoulos, The Role of Government in Anti-Social Redistributive Activities, March 2005

1428 Ansgar Belke and Daniel Gros, Asymmetries in the Trans-Atlantic Monetary Policy Relationship: Does the ECB follow the Fed?, March 2005

1429 Sören Blomquist and Luca Micheletto, Optimal Redistributive Taxation when Government's and Agents' Preferences Differ, March 2005

1430 Olof Åslund and Peter Fredriksson, Ethnic Enclaves and Welfare Cultures - QuasiExperimental Evidence, March 2005

1431 Paul De Grauwe, Roberto Dieci and Marianna Grimaldi, Fundamental and NonFundamental Equilibria in the Foreign Exchange Market. A Behavioural Finance Framework, March 2005 
1432 Peter Egger, Stefan Gruber, Mario Larch and Michael Pfaffermayr, Knowledge-Capital Meets New Economic Geography, March 2005

1433 George Economides and Apostolis Philippopoulos, Should Green Governments Give Priority to Environmental Policies over Growth-Enhancing Policies?, March 2005

1434 George W. Evans and Seppo Honkapohja, An Interview with Thomas J. Sargent, March 2005

1435 Helge Berger and Volker Nitsch, Zooming Out: The Trade Effect of the Euro in Historical Perspective, March 2005

1436 Marc-Andreas Muendler, Rational Information Choice in Financial Market Equilibrium, March 2005

1437 Martin Kolmar and Volker Meier, Intra-Generational Externalities and InterGenerational Transfers, March 2005

1438 M. Hashem Pesaran and Takashi Yamagata, Testing Slope Homogeneity in Large Panels, March 2005

1439 Gjermund Nese and Odd Rune Straume, Industry Concentration and Strategic Trade Policy in Successive Oligopoly, April 2005

1440 Tomer Blumkin and Efraim Sadka, A Case for Taxing Education, April 2005

1441 John Whalley, Globalization and Values, April 2005

1442 Denise L. Mauzerall, Babar Sultan, Namsoug Kim and David F. Bradford, Charging $\mathrm{NO}_{x}$ Emitters for Health Damages: An Exploratory Analysis, April 2005

1443 Britta Hamburg, Mathias Hoffmann and Joachim Keller, Consumption, Wealth and Business Cycles in Germany, April 2005

1444 Kohei Daido and Hideshi Itoh, The Pygmalion Effect: An Agency Model with Reference Dependent Preferences, April 2005

1445 John Whalley, Rationality, Irrationality and Economic Cognition, April 2005

1446 Henning Bohn, The Sustainability of Fiscal Policy in the United States, April 2005

1447 Torben M. Andersen, Is there a Role for an Active Fiscal Stabilization Policy? April 2005

1448 Hans Gersbach and Hans Haller, Bargaining Power and Equilibrium Consumption, April 2005

1449 Jerome L. Stein, The Transition Economies: A NATREX Evaluation of Research, April 2005 